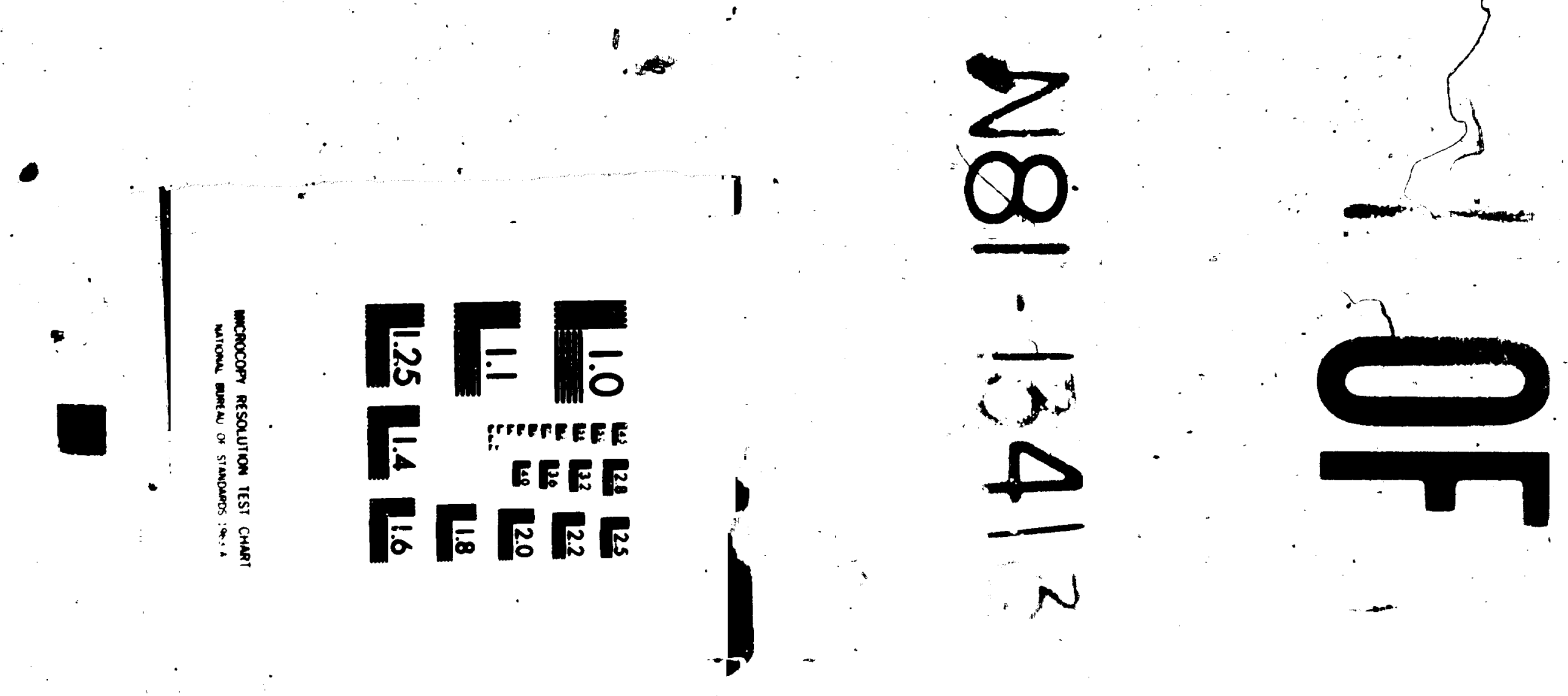


.........

\section{APPLICATION OF DIGITAL TERRAIN DATA TO QUANTIFY AND REDUCE THE TOPOGRAPHIC EFFECT ON LANDSAT DATA}

C. O. Justice, S. W. Wharton and B. N. Holben

(281-10055) APPLICATION OF DLGLTAL TEMAIIA 4 a 1-13413 DATA TO GUAUTLF AND LEDUCE THE TUPOLKRPHIC LRPECT OU LA DDSAT DATA (MASA) is HC AJJ/RP AU 1 CSCL USB 63/43 $\begin{array}{ll}\text { Unclas } \\ 00055\end{array}$

\section{AUGUST 1890}

National Aeronautics and Spece Administration

Coddurd spoco Flloht Center Greenbett. Maryland 20771

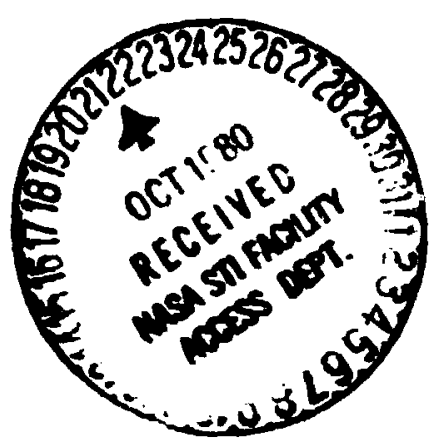




\section{APLUCATION OF DIGTTAL TERRAN DATA TO QUANTIFY AND \\ REDUCE THE TOMOCRAMHK EFFECT ON LANESAT DATA}

C. O. JUSTKCE*

S. W. WHARTON

B. N. HOLEEN

Earth Resources Branch (Code 923)

MASA/GSFC

Greenbelt, MD 20771

USA

August 1980

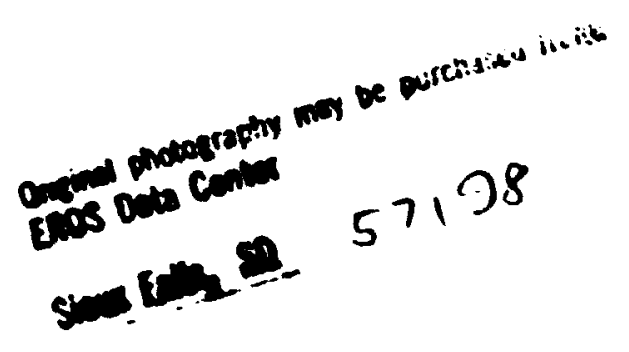

*C. Justice is an NRC Resident Research Associate at NASA/GSFC 


\section{ANPLKATION OF DICTTAL TERRAIN DATA TO QUANTIFY AND REDUCE THE TONCGRAMHIC EFFECT ON LANDSAT DATA}

\section{Introductuon}

The topogrephic effect is defined as the variation in radiances from inclined aurfeces compared to radiance from a horizontal surface $a$ a function of the orientation of the merfaces relative to the light source and sensor position (Holben and Juatice i 280 ). On Landast imaves of nuped terrain. this effect is manifested by the visual impresaion of relief (figure 1). Holken and Justice (1979) measured the topopraphic effect on remotely sensed data and showed the effect to be most extreme at low solar elevations and grestest for slopes in the principal plane of the sun. They abo showed by a Landsat simulation study that the tupopraphic effect can produce a comaderable variation in radiances amociated with a given cover type and may lead to poor cover-clascification mosults. Sadowski and Malila (1977) demonstrated that reflectances vary as a function of slope and aspect and that such terrain variations complicate the tash of dis sriminating woodland categories with remotely sensed data. Several other studies have deriu.astrated the need to consider tonopraphic variations when undertaking Landsat cover classification for areas of mountainous terrain (Hoffer and Staff 1975. Anuta 1976. Milker et al. 1978. Strahler et al. 1978. Hoffer et al. 1979. Strahker et al. 1979. Williams and Miller 1979).

The ahove studies incorporated elevation data with Landsat data to improve cover classification accuracies. Removal or reduction of the topographic effect before classification will reduce :he variation associated with the radiance for a given cover type and thereby increase the likelihood of class separability. Sadowski and Malila (1977) showed that changes in reflectance resulting from different topogaphic location resulted in spectral overlap of forested and nonforested sites. Williams et al. (1979) demonstrated that the utility of Landsat data for mapping gypsy moth defoliation of forest canopies in the mountains of central Pennsylvania was severely restricted by topographic variations. This restriction was most pronounced in separating levels of defoliation on slopes of different orientations. 
The objective of this study is to quantify and reduce ste topogrephic effect found in Landwa data for an area adjacent to that examined by Williams ef d. (1979) in centrel Pennsyhania. The next secition of the paper describes the field area selected for this study and the methods and data base used in the analy sis. The third section discuses four techniques for reducing the topopaphic effeci. The fourth section examines the strength of topowaphic effect in the data and the effectiveness of the four techniques for reducine the effect. The firth section summarizes the results of the analysis and diacuses the implications of the results.

$\therefore$ Descinption of study area. data base. and methouts

The study area is tocated in Perry County. north of Harrisburg. in central Pennaylvania and is contained within the 7.5 -minute Reward quadrande (fraure I). The ridoe and valley topography of the area. formed from a serses of eroded anticlines and synelines. is composed of Ondovician limestones. sandstones. and shales. running northeast to southwest across the area. Bufrabo Mountain. the ridge examined in this study. runs linearly northeast to southwest, with a maximam heint of $404 \mathrm{~m}$. The ndge was chosen for its constant slopes and aspects and uniform forest cover. Bloch diagrams created from the digital terrain data show the topography of the sludy area ffeures :and 3). Buffalo Mountain has three major slope units. moderate $\left(1{ }^{\circ} 4^{\circ}\right)$ and steep (ca $\left.22^{\circ}\right)$ rectilinear slejes of northuewt sopect and moderate $18.15^{\circ}$, slopes of southeast aspect. The ridge is covered hy a mixed decistous oak u(xodland consisting predominantly of white oak. red oak. shesinut oak. and hiack oak. A field visit to the study area reveaked complete crown closure throughout the study area and minimum differences in the cover type. distribution. and denaity between the two predominant aspects.

Tw's types of data were integrated to provide the data base used in this study: namely, Landsat multis e:tral scanner (MSS) data and digital terrain data. The image-processing system used for this study was the IDIMS (Interactive Digital Image Manipulation System) produced by E.S.L. (Electromagnetic System Lahoratory) Inc: the particular installation is at NASA/Goddard Space 
Finght Center (GSFC). Cireenbelt. MD. USA. It is comprised of a Hewlett-Packand 3000 minicomputer with a programmable array poneseor and specifuc software for imax analysis. The vanous data planes used in the study were created as image fiks on the IDIMS system.

The Landsat data ihosen for this study were for July 19. 1976. with a solar elevation of $55^{\circ}$ This hqh-aun-angle image was selected hecause it depkits the poriod of maximum foliagx. which enahkes optımum diunminatıon (Williams ef al 1979). Furtivemore. if depicis a time ilose to the ummer wlstice. when th: lopographic effect is at a minimum (Holten and Justke 1979). and is moxt likely. therefore. It. . . husen for analy sis of cover :ypes. From the raw Landsat data the MSS - 5 and o 5 hand-ratio images were created. Fe- ease of integration the Landsat data were resampled to $50 \mathrm{~m}$ and icaistered to the $1: \mathbf{4 . 0 0 0}$ topopraphic sheet.

The digutal terran data used in this study were the 30-m Deqital Flevation Model (DFM) data whtatned from the ('.S. Cicologinal Survey (USCiS) Digital Applications Team. Reston. Virginia (figure 4). The DH:M data should be distinguished from the 200-font Deiense Mapping A cency data. also avalable from the USX iS. The coarser resolution of the latter has heen criticized with referencic to the usefulness wi the horiontal resolution and the height aciuray (Stow and Estes 1479). The DFM data are dervied from orthophotos and are available for selected 7.5 -minute ạuadrangles within the USA (M.I. wien and Flassal 1478).

The height accuraty of the DFM data was evaluated hy comparing 91 elevation control points on the topographic map with the corresponding height values for the same locations from the terrain data before the data recampling. The average deviation of the DEM height values from the corresponding tupouraphic map values was $5.92 \mathrm{~m}$. Further examination of the hest matching point within a $3 \times 3$ window of the DEM data reduced the average variation to $2.79 \mathrm{~m}$. The DEM data were well within the 7-m height accuracy claimed by the USCS (Elassal 1980). From the $50-\mathrm{m}$ resampled DEM elevation data, both slope (figure $5 \mathrm{a}$ ) and aspect (figure $5 \mathrm{~b}$ ) were calculated for each elevation point. by use of a four-cell elevation matrix. by applying a modification 
of an aleorithm developed by Sharpnack and Akin ( 1969). Software was developed to uxe slope. aspect. solar elevation. and azimuth to iakulate the incidence angk for each pixel (fiare Sc). The Landsat data were registered to the -5 -minute topographic map for the Reward Quadrangde and the eight surrounding map quadrangles. Fighty-four eventy dispersed control points were chosen for the map sheets and the $I$ andsal data. The ront mean square (rms) etror was 0.79 pixets. anu ine maximum error was 1.75 pixels. The five control points located within the Reward Quadrangle had a rms of 0.73 pixels. with a maximum error of 1.03 pixels.

3. Techniques. vaninid for reducing the topographic effect

Four techniques for reducing the topographic effect are examined in this study. namely. spectrathand ratioing and application of a Lambertian model, a modified Lambertian model. and a non-Liamhertian model.

Spectral-hand ratioing in its simplest form consists of dividing the radiance values in one channel by the corresponding radiarlic valuev in a xesond channel. Ratioing has been proposed as a way of reducing mult nlicative stfict, within multispectral data. e.g.. by Kriegler et al. (1969). Crane 199711 . and Vincent 199731 . The topographic effect of direct light is one such multiplisative effect. I kialed aciount of hand ratwing as a fechnigure for reducing the topographic effect on ground-based radiometer data is presented by Holhen and Justice (1980). who showed that ratioing reduced the topographic effect on their data by an average of $x .3$ per cent. However. a study by Williams et al $(1979)$ on Landsat data of central Pennsylvania showed the spectralband ratioing did not remove slope- and aspect-induced variations to enaile improved classification.

The second technique examined was the application of a Lambertian reflectance model. This model is descrihed by Justice and Holben (1979) and is based on the assumption that the surface being sensed is Lambertian. A Lambertian surface is one that scatters light equally in all directions. The radiance from the surface can therefore be modelled by the cosine of the incidence angle, where the incidence angle is the angle between the surface normal and the solar beam (Robinson 19651. 


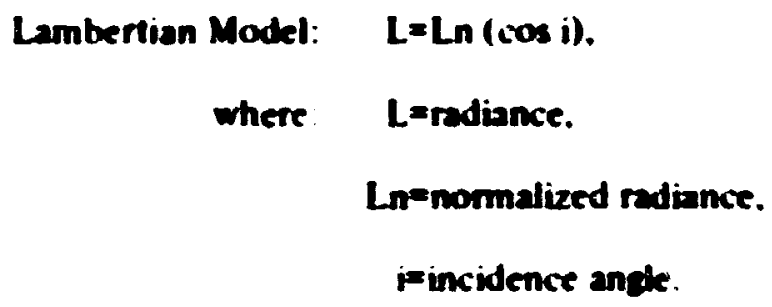

The Lambertian model zsoumes the reflected liaht to be directly proportional to the incident light. The relationshap hetween dala derived with the Lambertian model and radiances received hy eround-based sensors was examined by Holben and Justice (1979). there was a strone statistical relationship thet ieen the data sels. The Lambertian model has teen examined for correcting sun angle and topographic effects in Landsat data (Cicone ef al. 1977. Justice 1978. Hoffer et al. 1979. Tom ef al. 1979. Smith et al. 1980. Strahker ef al. 1979). Hoffer ef al. (1979) applized the Lambertian model to Landsat data and found that this correction slightly decreased classification accuracy for a range of fores? cover types. Smith ef al. (1 480$)$ found that the Lambertian assumption was only valid over a small range of incidence angles for pine-forest cover types. Cicone et al. (19??) found high statistical correlations setween Landsat radiances and incidence angle. hut found that the Lamhertial model overi:artected the data. To compensate for this overciorrection. Cicone et al $(1477)$ moditied the Lambertian assumption by multuply ing the slope angle by the solar zenith angle and then salculating the incidence angle. This modification was determined empirically with data for two solar elevations. and it led to improvements over the Lambertian model.

All natural surfaces have preferrej orientations of seattering (Kriehel 1976. 1978). and thus they are more satisfactorily modelled by a non-Lambertian model. Smith et al. (1980) applied a non-Lambertian nodel to Landsat data. using a function developed by Minnaert $(1941$. 1961). The model takes into consideration the incidence angle and the exitance angle made with the surface, us a function of $k$. a constant value. 


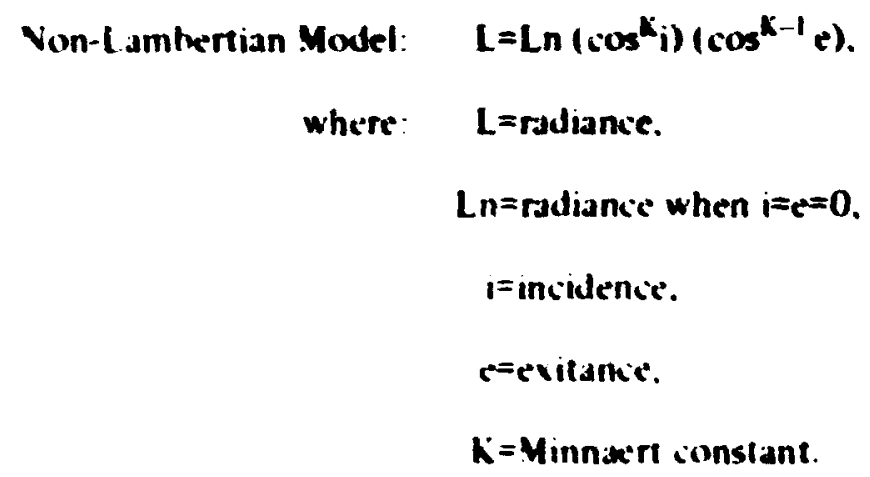

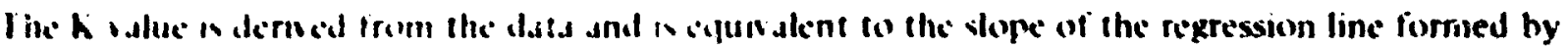

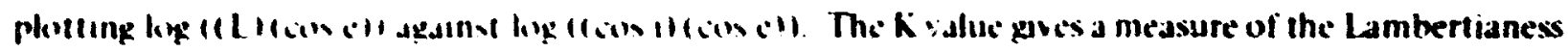

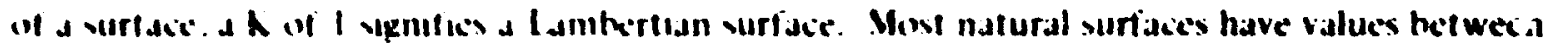

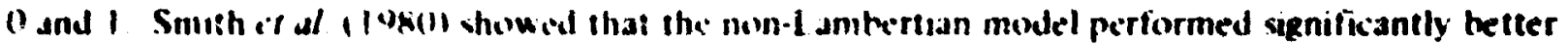
- han the Lambertian midel in reducing le rtam-inducied variations on pinc woodland. Justice and

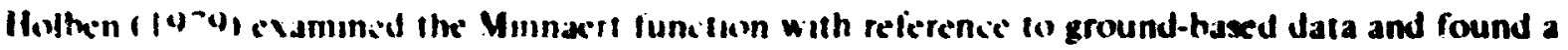

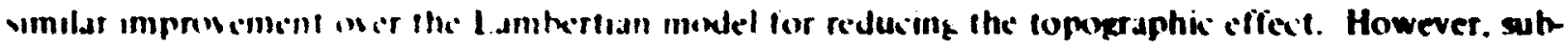

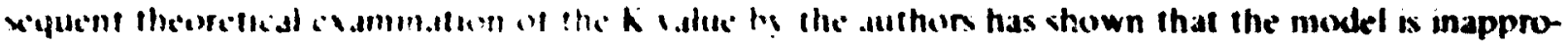

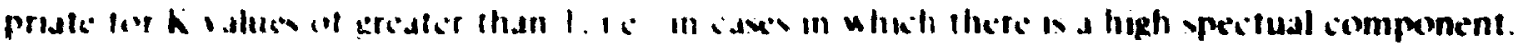

\section{+11 sin:}

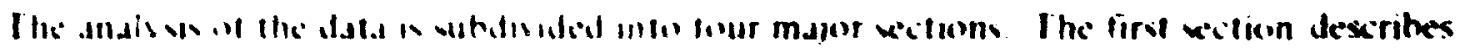

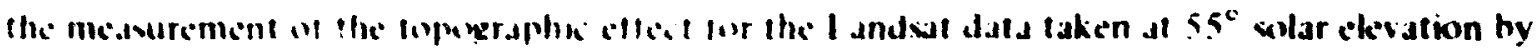

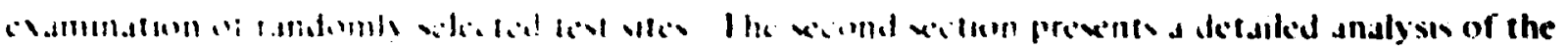

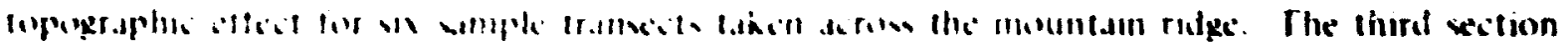

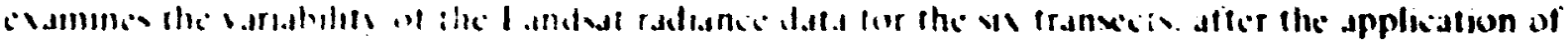

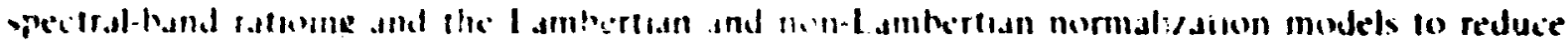

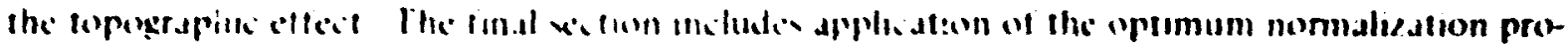

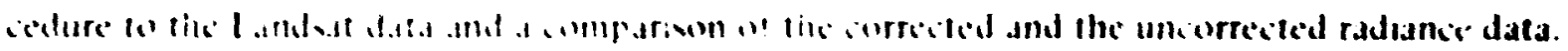




\subsection{The topographic effect on selected test sites}

The Landsat data of the Reward Quandrangle for MSS $7(0.8-1.1 \mu \mathrm{m})$ (figure 6) show the topographic effect on Buffalo Mountain ridge. which runs northedst-southwest across the image. The deciduous woodland canopy has a high reflectance in tine infrared for both dominant aspects. but the northwest slope of the ridge facing away from the sun is visibly darker than the southeast slope. The MSS 4 and 5 (figure 7$)(0.5-0.6 \mu \mathrm{m}$ and $0.6-0.7 \mu \mathrm{m}$ ) show no visible topographic effe:t. because of the low reflectivity of the woodland canopy in these two channels allowing the atmospheric path radiance to dominate. The major variation that can be seen on the mountain ric ze in channels 4 and 5 is caused by sensor banding. This is probably because at low reflectances the topographic effect, although present, is obscured by the quantization of the MSS sensor system (Holben and Justice. 1980). The MSS $6(0.7-0.8 \mu \mathrm{m})$ image was visually similar tu that of MSS 7 .

F or demonstration of the topographic effect on the Landsat data. three type sites were chosen to represent the major slope-aspect combinations on Buffalo Mountain. namely, southeast aspect and moderate slopi. northwest aspect and moderate slope. and northwest aspect and steep slope. Tast sites were randomly selected for each of the three locations along the mountain ridge. Four sites cotaling 767 pixels wer: selected for the southeast aspect location. Four sites totalirg 660 pixcls and five sites totaling 213 pixels were selected for the northwest aspect moderate-and stecp-slope sites. respectively. The number of pixels in the latter class was restricted by the extent of the slope class. Mean solar incidence angles of $44.5^{\circ} .61 .7^{\circ}$. and $73.5^{\circ}$ were calculated for the southeast-aspect moderate slopes. northwest-aspect moderate slopes. and northwest-aspect steep slopes. Calculation of mean pixel values for each test site revealed distinct grouping in MSS 6 ind ? with respect to aspect (figure 8 ).

Field checking of the sites before the analysis had shown no observable differences in "he woodland cover for the three locations. The differences in the mean pixel values were therefor associated primarily with the topographic variation. The highest mean pixel values associated with the oak woodland cover were in MSS 6 for the southeast aspect. However. the highest individual 
radiances ucr: fur MSS ${ }^{-}$. which was quantized to 64 levels. half the quantization level of the other three channels. The northwest-aspect mojerate-slope radiances for MSS 6 and MSS 7 were higher than the steer-slope radiances for the same aspect. Three distinct ranges of mean pixel values were ohtained for the threc slope-aspect classes for MSS 6 and 7 . For MSS 6 a difference of 17 pixel vahes separated the mean values for the sites associated with the southeast and northwest aspects. Such a large range indicates that selection of training sites for cover classification from one slopeaspect location may not adequately describe the raliances from the same cover from other locations. The degrea to which this m. y affect the classification results depends largely on the location and distribution of other cover-class radiances within the classification-feature space.

\subsection{Analysis of sample transicts}

Six sample transeits of landsat data across the mountain ridge were tak 2 n to examine the topographic effect in detail and to assess the statistical relationship between the Landsat radiances and the data derned with tlac propoxed models. Fach transect contained 20 pixels of Landsat dited The mean pivel sicues vindiard deviation. and range were calculated tor each transect (table

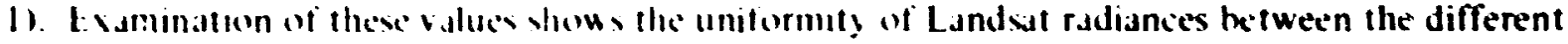
transets In MSS o. Iramed : had the greatest range. 21 pixel values. and in MSS 7. Transect o

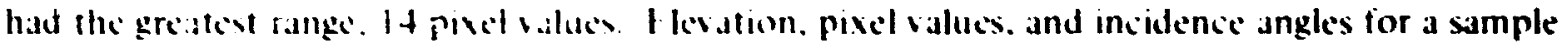

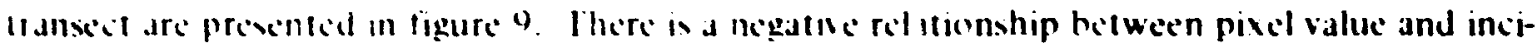
dence angle: the lowest pal values were dsociated with the highest incidence angles and vice versid.

The statistical relationshin letween the radiances and the data derived from the models was

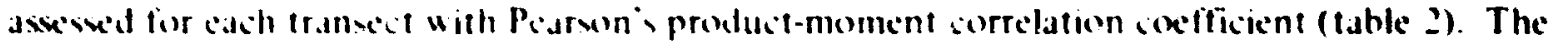

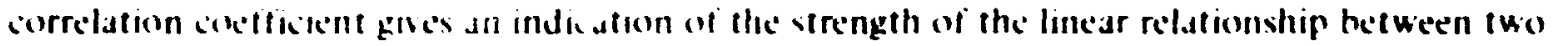

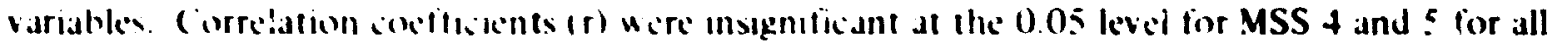
three model. Strong poitue relationships $(r \geqslant 0.84)$ were found for data derived with the Lam-

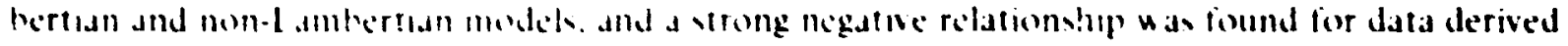


with the modified Lambertian model for all transtets. There was no substantial difference in the size of the $\mathrm{r}$ values among the three models.

\subsection{Evaluation of topographic effect reduction techniques}

Spectral-band ratioing and the three models were assessed for reducing the topographic effect on Pennsylvania Landsat jata.

Coefficients of variation (CVs) were calculated for the ratios of MSS $6 / 5$ and MSS $7 / 5$ for each transect and are presented for comparison with CVs for the raw data (table 3). The ( V is the standard deviation divided by the mean value, and it is used to compare variations within data sets. In this study a decrease in topographic effect is signified hy a decrease in the $\mathrm{C} /$. The CVs indicated a greater variation in the MSS 7/5 ratio :han in the MSS 6/5 ratio, because of the higher variation in MSS 7. The CVs for MSS 6/5 and 7/5 ratios decreased slightly from the CVs for the raw MSS data for three out of six transects. The poor reduction in the topographic effect by the MSS 6 5 and $7 / 5$ ratios is due to the negligible variation in MSS 5. The relatively constant radiance in MSS 4 and MSS 5 is associaied with the high absorpion by the green keaves of :he deciduous woodland and means that ratioing is effectively dividing MSS 7 and MSS :. oy a constant value.

Application of the Lambertian model to the data to reduce the topographic effect li.e.. di. vision of each pixel by cos i) led to a large increase in the ( $V$ for each transect over the variation for the raw data (table 3). Dividing the radiance from a Lambertian surface hy cos i normalizes the radiance to the equivalent radiance from a tlat surface with the sun overhead. This increase in the CVs is presumably due to the inapplicability of the Lambertian assumption for the wondland cover type in question. The largest CV was found for normalized MSS 4 and 5 data, probably because of the very small proportion of the MSS 4 and 5 radiance that was directly related to the variation in the incidence angle. i.e.. direct light reflectance. Over the riajority of slopes. the 
diffuse-light compon:nt appears essentially constant (Justice and Holben, 1980). The modified Lambertian model developed hy ("iconc $\therefore$ al. (1977) was a considerable improvement orer the Lambertian mudel in reducing the topugraphic effect (table 3), but for all transects, it increased the topograpliy-indluced vartittion atwere that found in the raw Landsat data.

Ipplication of the no.n-Lambertian model to the transect data involved calculation of the Minnaert $k$. alues for each tranicit (tuble +1 . The regression lines tised to calculate the $K$ values for MSS 4 and s had $r^{2}$ values of lew than 0.50 and were deemed invalid for any correction of the data. The lon $r^{2}$ values nerce a dircet result of the negligible variation in the MSS $f$ and 5 radiances. The regressen iime uxed w derme the $K$ values for MSS o and 7 had $r^{2} \geqslant 0.74$, with $k$ values ranging from 0.26 to 0.37 for MSS ? and 0.20 to 0.32 for MSS 6 . The $r^{2}$ values for these data were higher than thowe reported by Smith if al. 11980 ) and were less variable within the cover tyme. The value were then substituted in the non-Lambertian model $\left[\left(\cos ^{k_{i}}\right)\left(\cos ^{k-1} e\right)\right]$ for

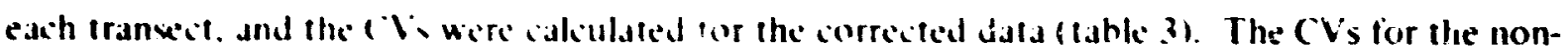
Lumbertian model uere markedly undiser than the ( V hor rau MSS o and data. The maximum

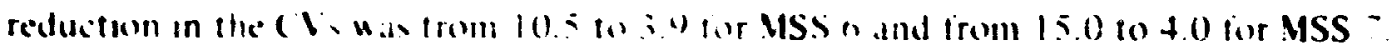

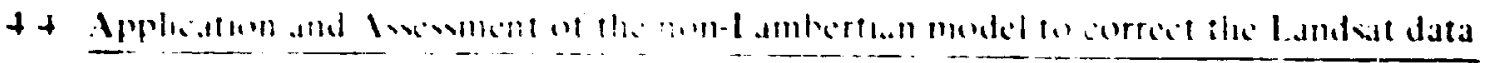

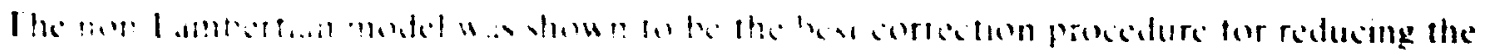

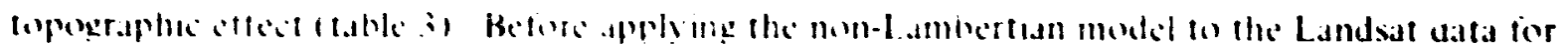

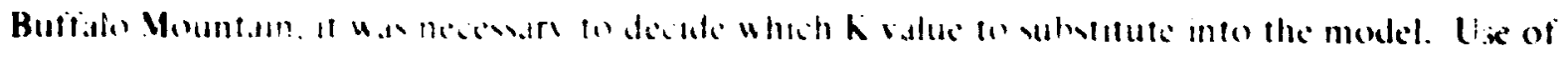

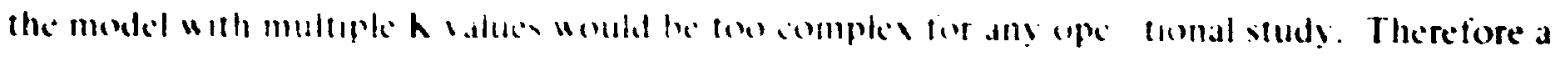

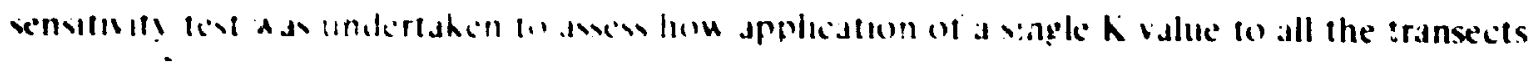

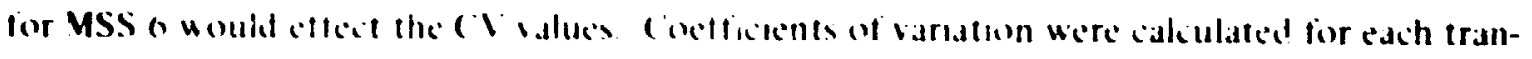

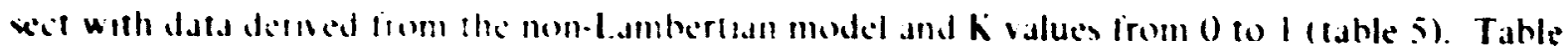

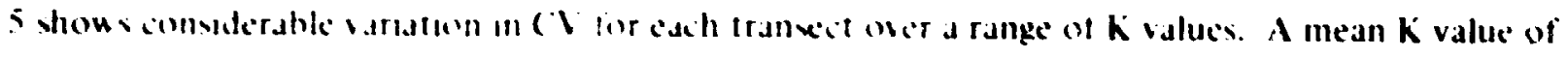

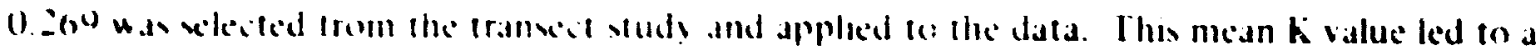


negligible change in the CV value from those derived with individual $\mathrm{K}$ values from each transect. The non-Lambertian model with a $\mathrm{K}$ value of 0.269 was applied to the MSS 6 data to prcduce a rurmalized image (figure 10). The effectiveness of the non-Lambertian model in reducing the topographic effect was determined by comparing the separability of radiance data for the threc dominant slope-aspect classes before and after normalization. Landsat data for three slope-aspect sites were extracted: 1125 pixels for the northwest moderate slope. 231 pixels for northwest steep slope. and 1480 pixels for the southwest moderate slope. The mean values and standard deviations are presented in table 6 and show that the difference in pixel values between the three sites was considerably reduced by the non-Lambertian model. The difference between the mean values for the northwest steep slope and the southeast moderate slope was reduced from 13.9 to 1.9186 per cent $)$ in MSS $6:$ ind from 9.7 to $1.2(87$ per cent $)$ in MSS 7 . The variation within the sites as measured by the standard deviation increased slightly in rhe corrected data by an average of 0.5 . The results show that the topographic effect was substantia..y reduced with the nonLambertian model.

5. Summary of results and conclusion

It is commonly suggested that Landisat cover-classification studies should be undertaken on imagery obtained at high solar elevation to reduce variations in spectral response becausc of the topographic effect. Results from this study show' that even high-sun-angle data have an apparent topographic effect tiat may confound cove- zassitication. Examination oi the June 1976 LandSat imagery shcwed a marked cifference between the radiances associated $w$ ith the three dominant slope-aspect combinations found in the study area. The topographic effect was evident for MSS ? and MSS 6 with a pixel-value range of 21 among randomly chosen transects across the study ridge. No topographic effect was apparent in MSS 4 and 5 because of a combination of high alisorption in those spectral channels by healthly deciduous vegetation and the Landsat quantization procedure.

Application of tour $r$ ethods for reúcing the topographic effect to the sample transects across the test ridge gave the following results: 
Spectral-hand ratioing (MSS 75, MSS 6 5 ) slightly decreased the variation of the Landsat data for 50 percent of the transects. Beialuse of the small variation in MSS S. ratioing could not eliminate the direct-light topographic effect, as the denominator of the ratio was virtually constant. This reasoning also may explain the poor results obtained hy Williams et al. $(1079)$ with bandratioing technicues.

When applied to the Landast data. the Lambertian model increased the topographic effect. This degradiation of the radiance is due to the inapplicahility of the Lambertian assumption to model the bidirectional reflectance harateristies of tile wowaland surface

The modified Lambertum model developed hy (isone d' al. $(1977)$ decreased the variation produced by applying the lambertion model hut gave even higher variances than those found in the raw Landsat data.

The non-Lambertam model developed hy Smith et al 1 1980 markedly decreased 1 208 per cent) the variation of the Landwt data. and. therefore, reduced the topopgraphic effect

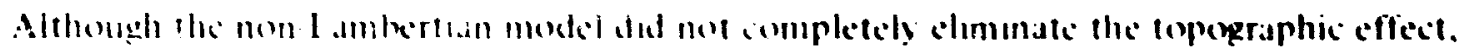

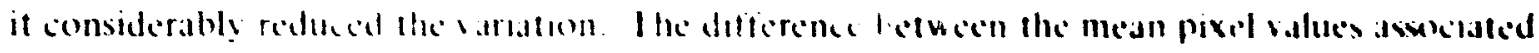

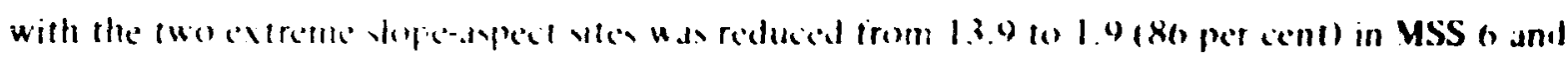

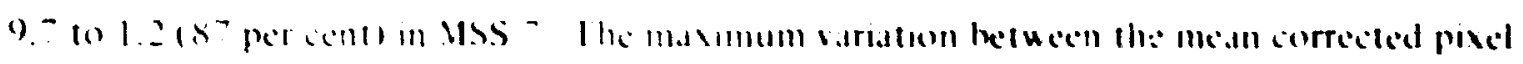

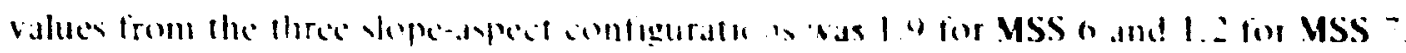

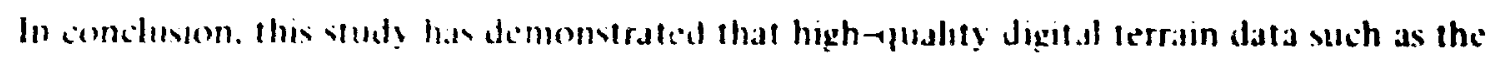
USC iS DEA datd can be used vis modelling to conhance the utility of multespectral satellite data. Digital terrain data can be used to develop snd lest improved radiative transfer models, which. in turn. may kead to improwed cover ilewilication of Land dat data.

Nhlough the study has demomeratid the sucien of a non-Lambertian model for reducing the topegraphe effet and the potental for preprocensing Land "datat. furtlier development of

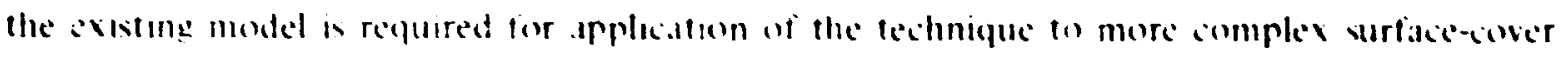
conditions. 


\section{Acknowledgments}

The authors thank the USGS Digital Applications Team at Reston. Virginia, particularly Atef Elassal and Frank Beck for providing the DEM data. We also thank Kevin Ingram, CSC, and Ed Masuoka, NASA/GSFC, for their assistance with this project and Anne Heasty, SSA Inc. for the technical editing of this paper. 


\section{References}

ANUTA, P. E., 1976, Proc. of 42nd Convention Am. Soc. Photogramm., pp. 180-87.

CICONE, R. C., MALILA, W. A., and CRIST, E. P., 1977, Investigation of techniques for inventorying forested regions. Final Report: Vol. II Forestry information sy'stem reguirements and joint use of remotely sensed and ancillary data. NASA-CR-ERIM $122700-35-F 2$.

CRANE. R. B., 1971. Proc. of 8th Internat. Symp. of Remote Sensing of Environment. Ann Arhor, Mich. pp. 1345-1355.

ELASSAL. A.. 1980 (personal communication), USGS. Reston.

HOFFER, R. M., and Staff, 1975, Vatural resource mapping in mountainous terrain by computer cnals sis of ERTS-1 satellite data. Laboratory for Agricultural Remote Sensing. Purdue. Ind. Information Note 061575.

HOFFER, R. M., FLEMING. M. D., et al., 1979, Digital processing of Landsat MSS and topographic data to improve capahilities for computerized mapping of forest cover types. LARS Tech. Rep. 011579.

HOLBEN, B. N., and JUSTICE, C. O.. 1979. Evaluation and modeling of the topographic effect on the' spectrci responsc from nudir pointing sensors. NASA TM 80305. Goddard Space Flight Center, Cireenhelt. MD.

HOLBEN, B. N . and JUSTICF, C. O., i980. An examination of spectral band rutioing to reduce she topographic effect on remote's se'nsed data. NASA TM 80640. Goddard Space Flight (inter. Greentelt. MD.

JeSTICl ( (). 1978. Proc .1m. Soc Phorogramm Fall Mrg. Albuquerque. New Mexico, pp. $303-328$.

JUSTIC 1 . ( . (). and HOLBH.N. B. N., 1979. R.xamination of Lambertian and non-Lumbertian models for simulatmg the tonographic effect on remotely sensed data. NASA TM 80557. Goddard Space Flight Center. Greenbelt. MD.

JUSTICK., . (). and HOLBEN. B. N. 1980. The ('omtribution of the diffuse light component to the toplographic effect on remotely sensed duta. NASA TM 85.290. Cinddard Space Flight Center. Gireenbelt. MD.

KRIFBF L. T. K. 1976. Re'mole' St'nsing tinviron 4. 257-64.

KRIt:BE L. T. K.. 1978. Appl. Optics 17. 253-259. 
KRIEGLeR, F. J., MALILA. W. A., NALEPKA, R. F., and RICHARDSON. W.. 1969, Proc. Intemat. Symp. on Remore Sen ng of Environ., Vol. 1, Ann Arbor. Mikh., Oct. 13-16, 1969. pp. 97-109.

MCEWEN. R. B.. and ELASSAL, A. A.. 1978, Proc Intemat. Users Conf. on Computer Mapping Hardware. Software and Dato Bases. Harvard University. June 1978, p. 23.

MILLER. L. D.. NUALCHAWEE, K., ar.d TOM. C.. 1978. A nalysis of the dynamics of shifting cultivation in the tropical forests of northern Thailund using landscape modeling and classificati.n of Lundsat imagery. NASA TM 79545. Cioddard Space Flight Center. Cireenthelt. MD.

MINNAERT. M., 1941.J. Astrophys. 93.403-410.

MINNAFRT. M. I\%1, in G. P. Kuiper (ed.) The Solar System. Vol. III. Planets a Satellites. University of Chicago Press. pp. 213-249.

ROBINSON. N.. 1965. Solar Radiation. Ekevier Publ. Co., New York.

SADOWSKI. F. G.. and MALILA. W. A.. 1977, Investigation of techniques for inventorying forested regions Viol I Reflectunce moleling a empirical multispectral analisis of forest conom components. NAS-CR-ERIM-122700-35-FI.

SHAR PNACK. D. A.. and AKIN. G.. 1969. Photogram. Engng. 3. 247-48.

SMITH. J. A., LIN, T L.. and RANSON. K. J.. 1980. The Lambertian assumption and Landsat data. Phofogramm fingng. Remote Sensing (in the press).

STOW. D. A., and FSTES. J. F., 1979. Proc Simp on Machine Proce'ssing of Re'mote't Sensed Dafa. Latworatory for Agricultural Remote Sensing. Purdue. Ind., pp. 19,3-200.

STRAHIFR. A. H. LOXiAN. T. L.. and BRYANT. N. A.. 1978. Proc. I'th Internat. Simp on Remole Sensing of the Enrioron. Manila. Phillippines. Vol. 2.. pp. 927-056.

STRAHLER, A. H. LOCiAN. T. L.. WOODCOCK. C. E.. 1979. Proc I ith Internat Simp an Remote Sensing of Enriron., Ann Arbor, Michigan. Vol. III. pp. 1541-1555.

TOM. C.. MILLER. L. D., and CHRISTENSON, J. W., 1979, Spatial lund use inventerr. medeling and projection Denver Me(ropolitan Alea wirh inpurs from e'visfing maps. airphofos and Lundsut imagerv. NASA TM 79710. Gotdard Space Flight Center. Cireenbelt. MD.

VINCENT. R. K., 1973. Proc .4m. Soc. Photogramm. Monagement. Litlizalion of Remote' Sinsing Dura Conferences. Sioux Falls. South Dakota. pp. 377-39? 
WILLIAMS. D. L. and MILLER, L. 1). 1479. Monitoring forest canopy alterotion anound th:- world with digital unalvsis of Landwr imagery. Earth Resources Branch. NASA/Goddard Sprace Flight Conter.

WilliamS. D. L.. STAlffer. M. L.. and LFUNG. K. C.. 1979. Proc Symp. on Machine Prixcessing of Re'mercely Sensed Mura. pn. 3n8-375. 
Table 1

Mean, standard deviation, and range of Landsat pixel values for six sample transects across Buffalo Mountain, PA.

\begin{tabular}{|c|c|c|c|c|c|}
\hline \multirow[b]{2}{*}{ Tronsert } & \multirow[b]{2}{*}{$\begin{array}{l}\text { Multispectral } \\
\text { scanner }\end{array}$} & \multicolumn{3}{|c|}{ Pixel Value } & \multirow[b]{2}{*}{$\mathbf{N}$} \\
\hline & & Mean & $\begin{array}{l}\text { Standard } \\
\text { deviation }\end{array}$ & Range & \\
\hline \multirow[t]{4}{*}{1} & 4 & 16.1 & 0.64 & 2 & 20 \\
\hline & 5 & 12.6 & 0.68 & 2 & \\
\hline & 6 & 60.0 & 4.9 & 16 & \\
\hline & 7 & 34.2 & 3.2 & 9 & \\
\hline \multirow[t]{4}{*}{$\Sigma$} & 4 & 16.0 & 0.83 & 3 & 20 \\
\hline & 5 & 12.6 & 0.60 & 2 & \\
\hline & 6 & 59.0 & 4.8 & 15 & \\
\hline & 7 & 33.5 & 3.7 & 13 & \\
\hline \multirow[t]{4}{*}{3} & 4 & 16.2 & 0.64 & 2 & 20 \\
\hline & 5 & 12.3 & 0.73 & 2 & \\
\hline & 6 & 60.9 & 6.0 & 21 & \\
\hline & 7 & 34.5 & 3.7 & 13 & \\
\hline \multirow[t]{4}{*}{4} & 4 & 15.9 & 0.72 & 2 & 20 \\
\hline & 5 & 12.5 & 0.60 & 2 & \\
\hline & 6 & 59.3 & 4.6 & 15 & \\
\hline & 7 & 33.7 & 2.5 & 8 & \\
\hline \multirow[t]{4}{*}{5} & 4 & 15.8 & 0.87 & 3 & 20 \\
\hline & 5 & 12.6 & 0.74 & 2 & \\
\hline & 6 & 59.5 & 4.4 & 14 & \\
\hline & 7 & 34.0 & 3.1 & 12 & \\
\hline \multirow[t]{4}{*}{6} & 4 & 15.9 & 0.8 ? & 3 & 20 \\
\hline & 5 & 12.7 & 0.79 & 3 & \\
\hline & 6 & 61.6 & 6.5 & 18 & \\
\hline & 7 & 35.0 & 5.3 & 14 & \\
\hline
\end{tabular}


Table 2

Pearson's product-moment correlation coefficients ( $r$ ) for Landsat radiances and data derived from the radiance models for six transects.

\begin{tabular}{|c|c|c|c|c|c|}
\hline \multirow{2}{*}{$\begin{array}{c}\text { Transect } \\
\text { no. }\end{array}$} & \multirow{2}{*}{$\begin{array}{l}\text { Multispectral } \\
\text { :canner }\end{array}$} & \multirow[b]{2}{*}{$\mathbf{N}$} & \multicolumn{3}{|c|}{ Modelt } \\
\hline & & & 1 & 2 & 3 \\
\hline 1 & $\begin{array}{l}4 \\
5 \\
6 \\
7\end{array}$ & 20 & $\begin{array}{c}-0.39^{*} \\
0.13^{*} \\
0.88 \\
0.89\end{array}$ & $\begin{array}{l}-0.27^{*} \\
-0.08^{*} \\
-0.84 \\
-0.88\end{array}$ & $\begin{array}{c}0.20^{*} \\
0.01^{*} \\
-6.85 \\
0.88\end{array}$ \\
\hline 2 & $\begin{array}{l}4 \\
5 \\
6 \\
7\end{array}$ & 20 & $\begin{array}{c}-0.07^{\star} \\
0.26^{\star} \\
0.90 \\
0.89\end{array}$ & $\begin{array}{l}-0.02^{*} \\
-0.11^{*} \\
-0.93 \\
-0.87\end{array}$ & $\begin{array}{c}0.30^{*} \\
-0.11^{*} \\
0.89 \\
0.87\end{array}$ \\
\hline 3 & $\begin{array}{l}4 \\
5 \\
6 \\
7\end{array}$ & 20 & $\begin{array}{l}0.57^{*} \\
0.54^{*} \\
0.93 \\
0.91\end{array}$ & $\begin{array}{l}-0.57^{*} \\
-0.49^{*} \\
-0.84 \\
-0.79\end{array}$ & $\begin{array}{l}0.40^{*} \\
0.40^{*} \\
0.91 \\
0.90\end{array}$ \\
\hline+ & $\begin{array}{l}4 \\
5 \\
6 \\
7\end{array}$ & 20 & $\begin{array}{c}-0.20^{*} \\
0.57^{*} \\
0.96 \\
0.97\end{array}$ & $\begin{array}{l}0.28^{*} \\
-0.52^{*} \\
-0.90 \\
-0.94\end{array}$ & $\begin{array}{l}0.24^{*} \\
0.44^{*} \\
0.96 \\
0.96\end{array}$ \\
\hline 5 & $\begin{array}{l}4 \\
5 \\
6 \\
7\end{array}$ & 20 & $\begin{array}{r}11.24^{*} \\
-6.28^{*} \\
0.84 \\
0.8^{4}\end{array}$ & $\begin{array}{l}-0.29 * \\
-0.28^{*} \\
-0.66 \\
-0.78\end{array}$ & $\begin{array}{l}0.43^{*} \\
0.08^{*} \\
0.85 \\
0.84\end{array}$ \\
\hline 0 & $\begin{array}{l}4 \\
5 \\
0 \\
7\end{array}$ & 20 & $\begin{array}{l}0.27^{*} \\
0.27^{*} \\
0.44 \\
0.9^{-}\end{array}$ & $\begin{array}{l}-0.32^{*} \\
-0.39 * \\
-1.94 \\
-0.95\end{array}$ & $\begin{array}{l}0.24^{*} \\
0.27 * \\
0.94 \\
0.90\end{array}$ \\
\hline
\end{tabular}

+ Model I Cosine I

Z Moditied cosine 1

3 Non-Lambertian model

* Insignificant at the 0.05 level of prohability. 


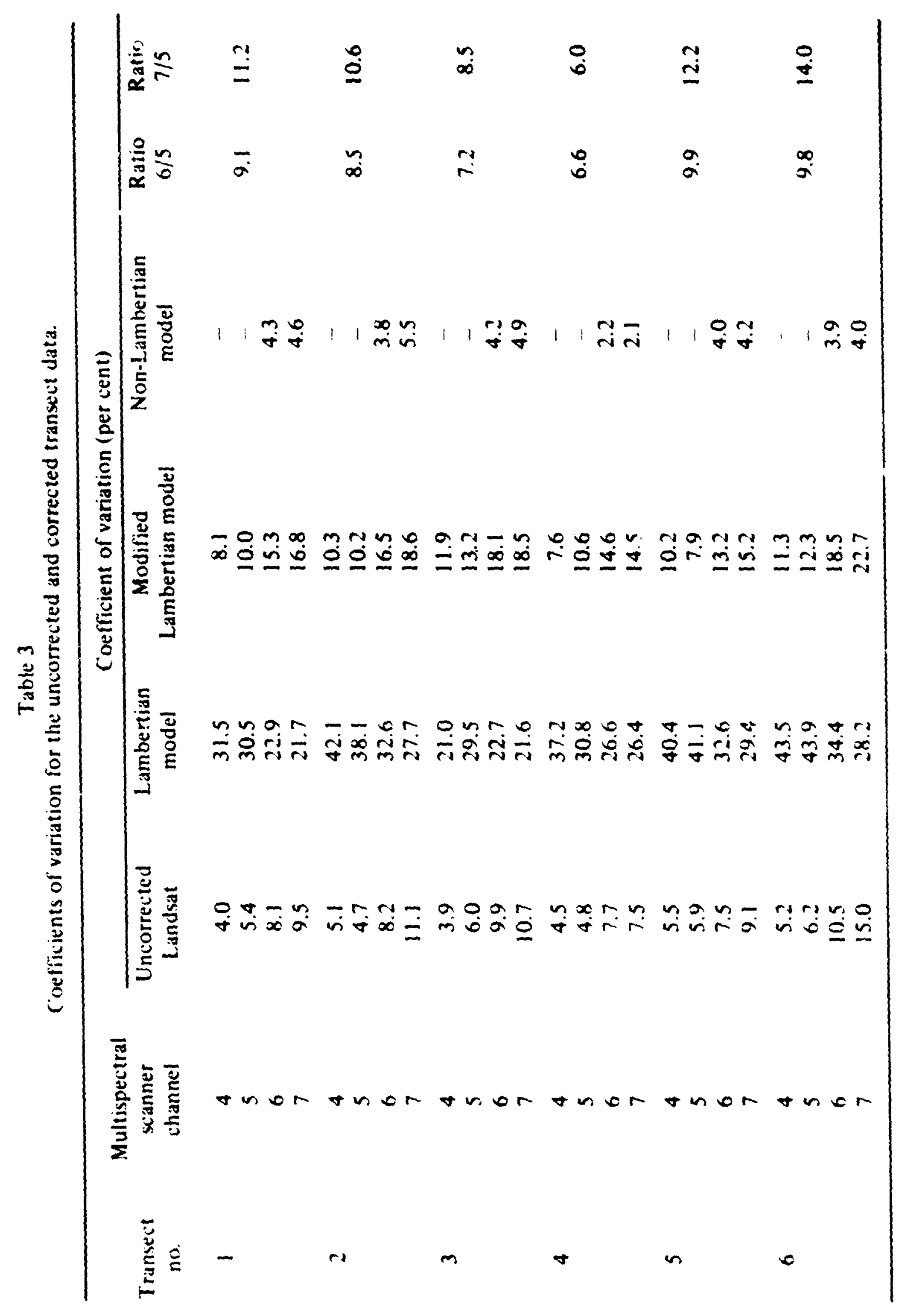


Table 4

Minnaert K ; alues and coriticients of determinatiou $\left(r^{2}\right)$ for the six sample transects.

\begin{tabular}{|c|c|c|c|c|}
\hline Transedt & $\begin{array}{c}\text { Multispectral } \\
\text { scanner } \\
\text { channel }\end{array}$ & $\mathbf{N}$ & $\mathbf{K}$ & $r^{2}$ \\
\hline \multirow[t]{4}{*}{1} & 4 & 20 & -0.04 & 0.07 \\
\hline & 5 & & 0.03 & 0.03 \\
\hline & 6 & & 0.26 & 0.76 \\
\hline & 7 & & 0.30 & 0.80 \\
\hline \multirow[t]{4}{*}{ 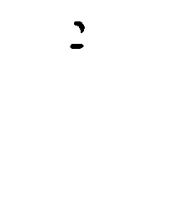 } & 1 & 20 & 0.01 & 0.00 \\
\hline & 5 & & 0.07 & 0.16 \\
\hline & 0 & & 0.22 & 0.83 \\
\hline & 7 & & 0.32 & 0.82 \\
\hline \multirow[t]{4}{*}{3} & 4 & 20 & 0.09 & 0.34 \\
\hline & 5 & & 0.13 & 0.34 \\
\hline & 0 & & 0.32 & 0.85 \\
\hline & 7 & & 0.35 & 0.84 \\
\hline \multirow[t]{4}{*}{4} & 4 & 20 & 0.01 & 0.01 \\
\hline & 5 & & 0.14 & 0.50 \\
\hline & 6 & & 0.27 & 0.94 \\
\hline & ᄀ & & 0.27 & 0.95 \\
\hline \multirow[t]{4}{*}{5} & 4 & 20 & 0.05 & 0.10 \\
\hline & 5 & & -1.02 & 0.01 \\
\hline & $n$ & & 0.20 & 0.74 \\
\hline & 7 & & 0.26 & 0.82 \\
\hline \multirow[t]{4}{*}{ n } & 4 & 20 & 0.05 & 0.13 \\
\hline & 5 & & 0.05 & 0.10 \\
\hline & 0 & & 0.25 & 0.89 \\
\hline & 7 & & 0.37 & 0.94 \\
\hline
\end{tabular}


Cofficients of variation ( $(V)$ for the non- Table $S$

substituting a range of Minneart $K$ values.

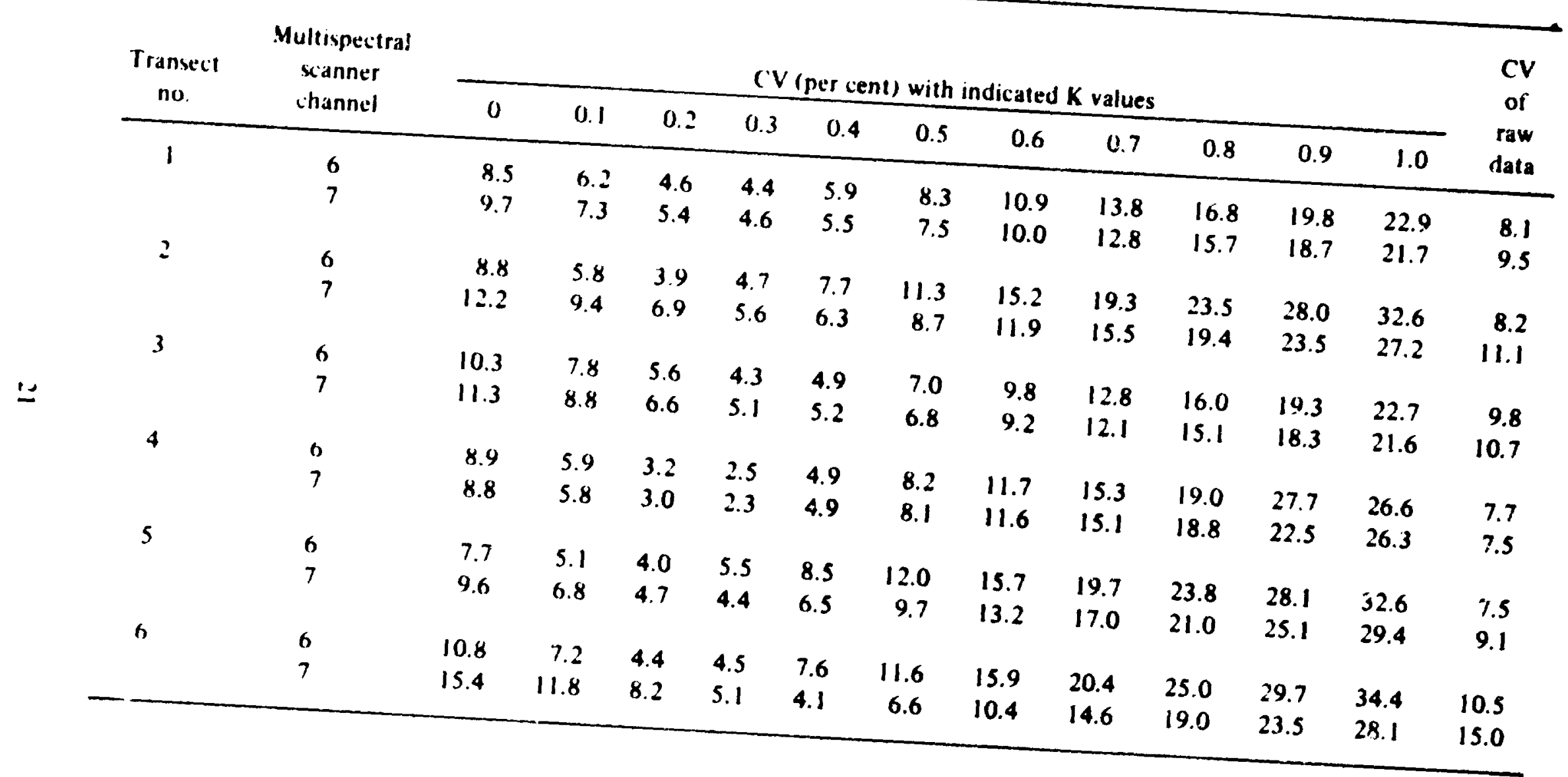


Table 6

Mean pixal values and standard deviations calculated for uncorrected data and data corrected with the non-Lambertian model for three slope-aspect sites.

\begin{tabular}{|c|c|c|c|c|c|c|c|c|c|c|}
\hline \multirow{4}{*}{ Slope-dispect stte } & \multirow{4}{*}{$\begin{array}{c}\text { Meiall } \\
\text { incidence } \\
\text { angle }\end{array}$} & \multirow{4}{*}{$\mathbf{N}$} & \multicolumn{8}{|c|}{ Pixei value } \\
\hline & & & \multicolumn{4}{|c|}{ Uncorrected data } & \multicolumn{4}{|c|}{ Corrected } \\
\hline & & & \multicolumn{2}{|c|}{ MSS 6} & \multicolumn{2}{|c|}{ MSS 7} & \multicolumn{2}{|c|}{ MSS 6} & \multicolumn{2}{|c|}{ MSS 7} \\
\hline & & & $\overline{\mathrm{x}}$ & SD & $\bar{x}$ & SD & $\bar{x}$ & SD & $\bar{x}$ & SD \\
\hline Northwest (moderate slope) & $62^{\circ}$ & 1125 & 56.3 & 3.3 & 31.9 & 2.1 & 68.4 & 4.1 & 40.0 & 2.6 \\
\hline Northwest (stecep slope) & $40^{\circ}$ & 231 & 50.7 & 2.2 & 27.8 & 1.3 & 67.0 & 2.9 & 39.7 & 1.8 \\
\hline Southeast (moderate slope) & $72^{\circ}$ & 1480 & 64.6 & 2.6 & 37.6 & 1.7 & 689 & 2.9 & 40.9 & 1.8 \\
\hline Maximum range in means & & & & & & & & & & \\
\hline
\end{tabular}


Figure 1. Location of the study area (rectangle) on Landsat MSS 6 image, December 1973, solar elevation $21^{\circ}$.

Figure 2. Block diagram of the Reward Quadrangie from the southeast, constructed with digital terrain data.

Figure 3. Block diagram of the Reward Quadrangle from the East. constructed with digital terrain data.

Figure 4. Digital elevation-model data of the Reward Quadrangle (dark areas represent low clevation. light areas represent high elevation).

Figure 5a. Slope angle map of the Reward Quadrangle created from digital elevation data. (Dark areas represent low slopes. light areas represent high slopes).

Figure 5b. Slope aspect map of the Reward Quadrangie created from digital elevation data. (lightest tone $=0^{\circ}$. darkest tone $=359^{\circ}$ ).

Figure 5c. Incide ice angle map of the Reward Quadrangle for $55^{\circ}$ solar elevation. (dark tones represent lou incidence angles. light tones represent high incidence angles).

Figure 6. Landsat MSS ? of the Reward Quadrangle.

Figure 7. Landsat MSS 5 of the Reward Quadrangle.

Figure 8. Plo: showing the distribution of mean Landsat pixel values associated with training sites from different slopes and aspects.

Figire 9. Elevation. incidence angles. and Landsat multispectral scanner 6 response for a sample transect across Buffalo Mountain.

Figure 10. MSS o data nomalized with the non-I.ambertian model. 


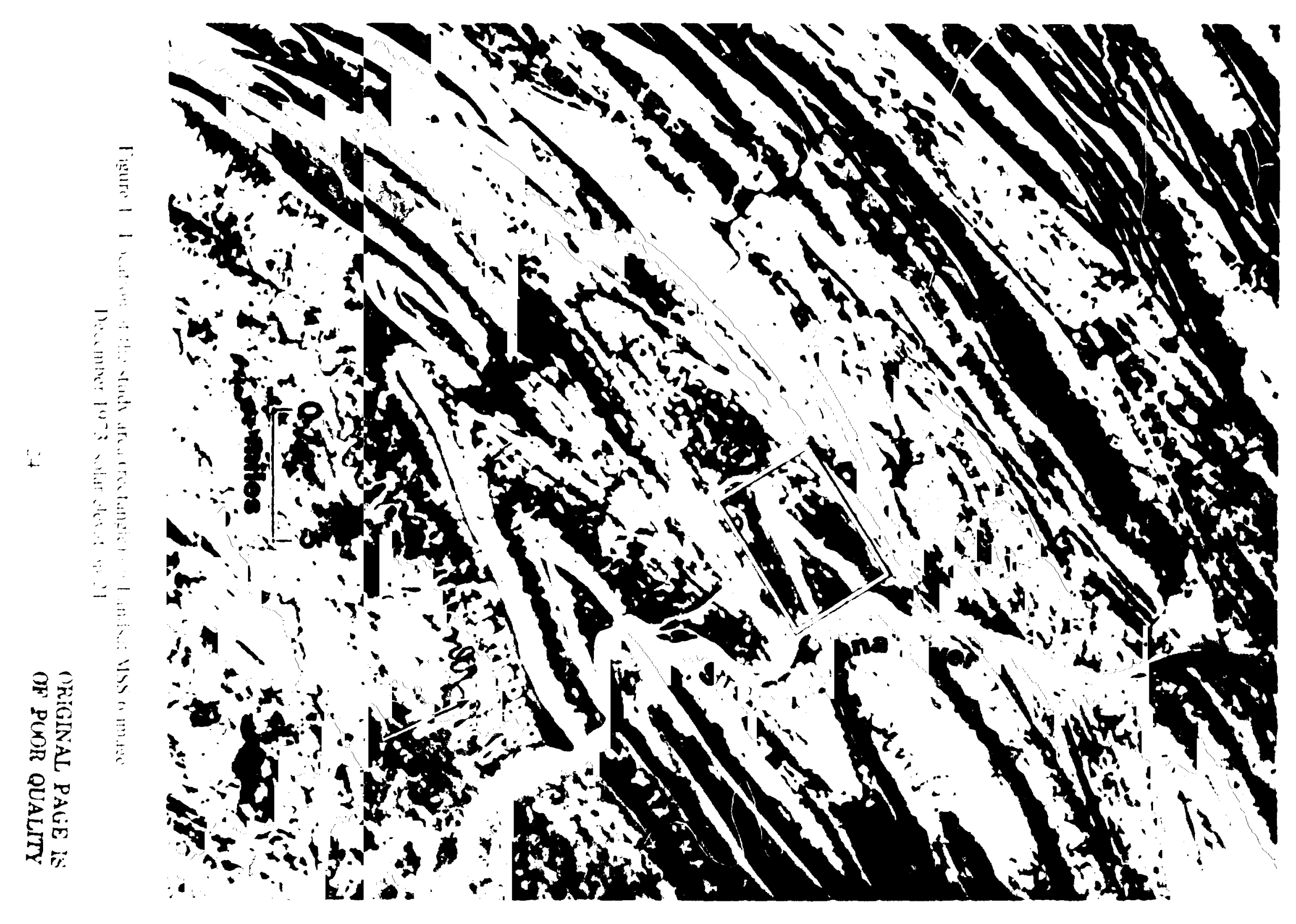




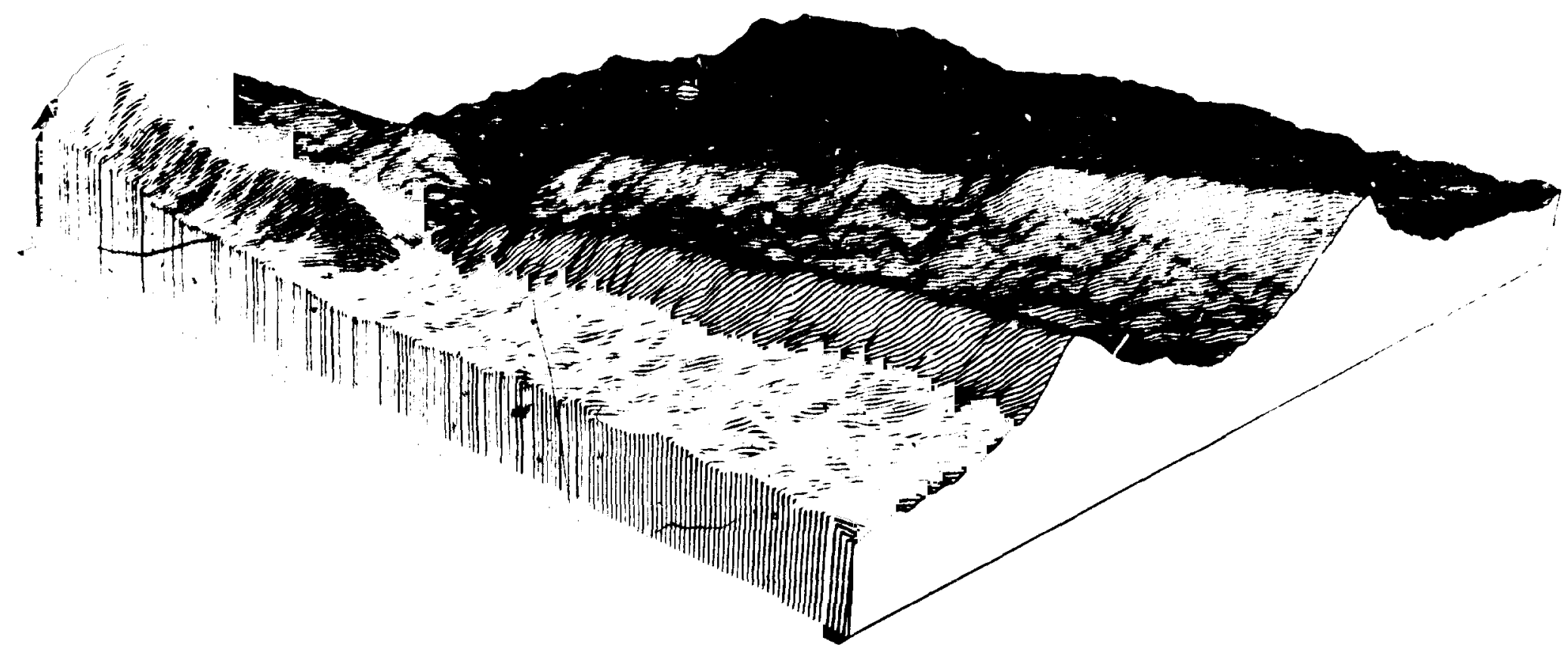

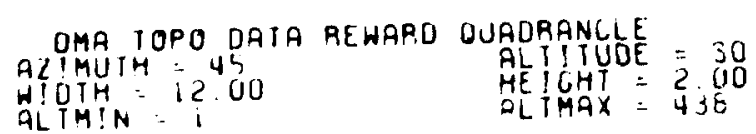

Figure 2. Block diagram of the Reward Quadrangle from the southeast, constructed with digital terrain data. 


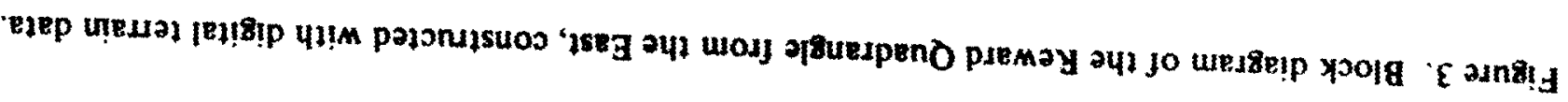

$$
\text { \$1 }
$$

a.: :

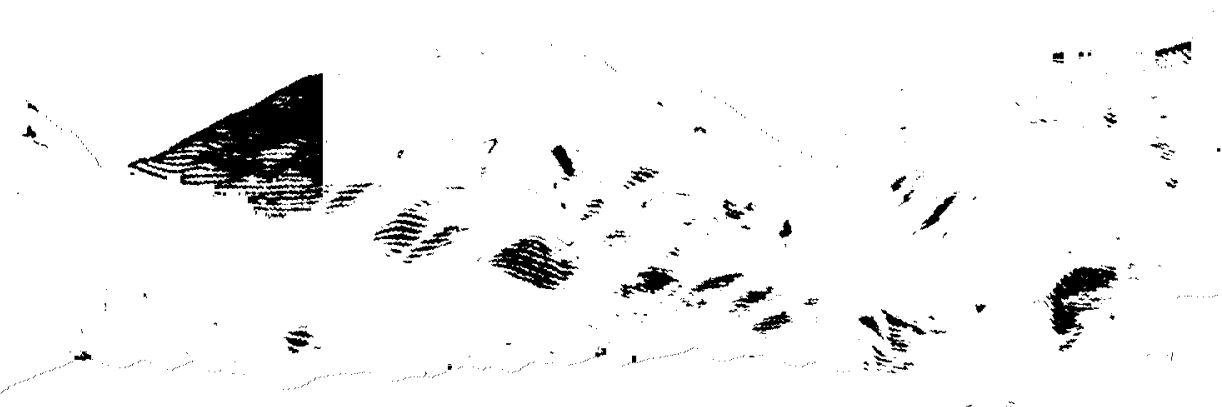




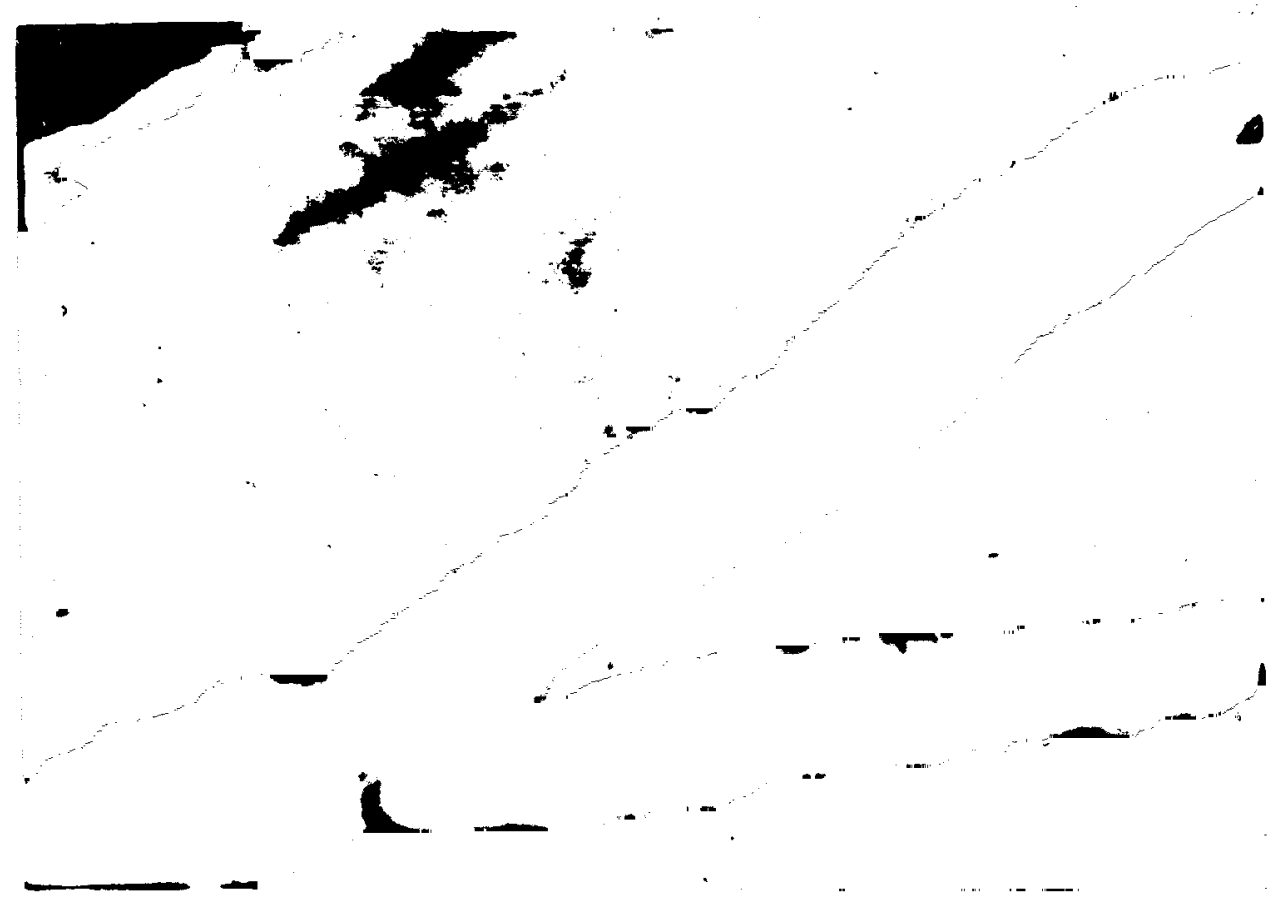

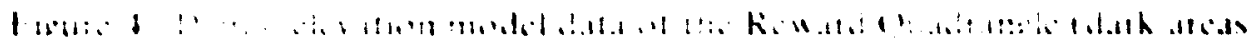

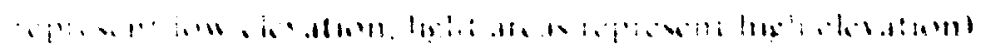

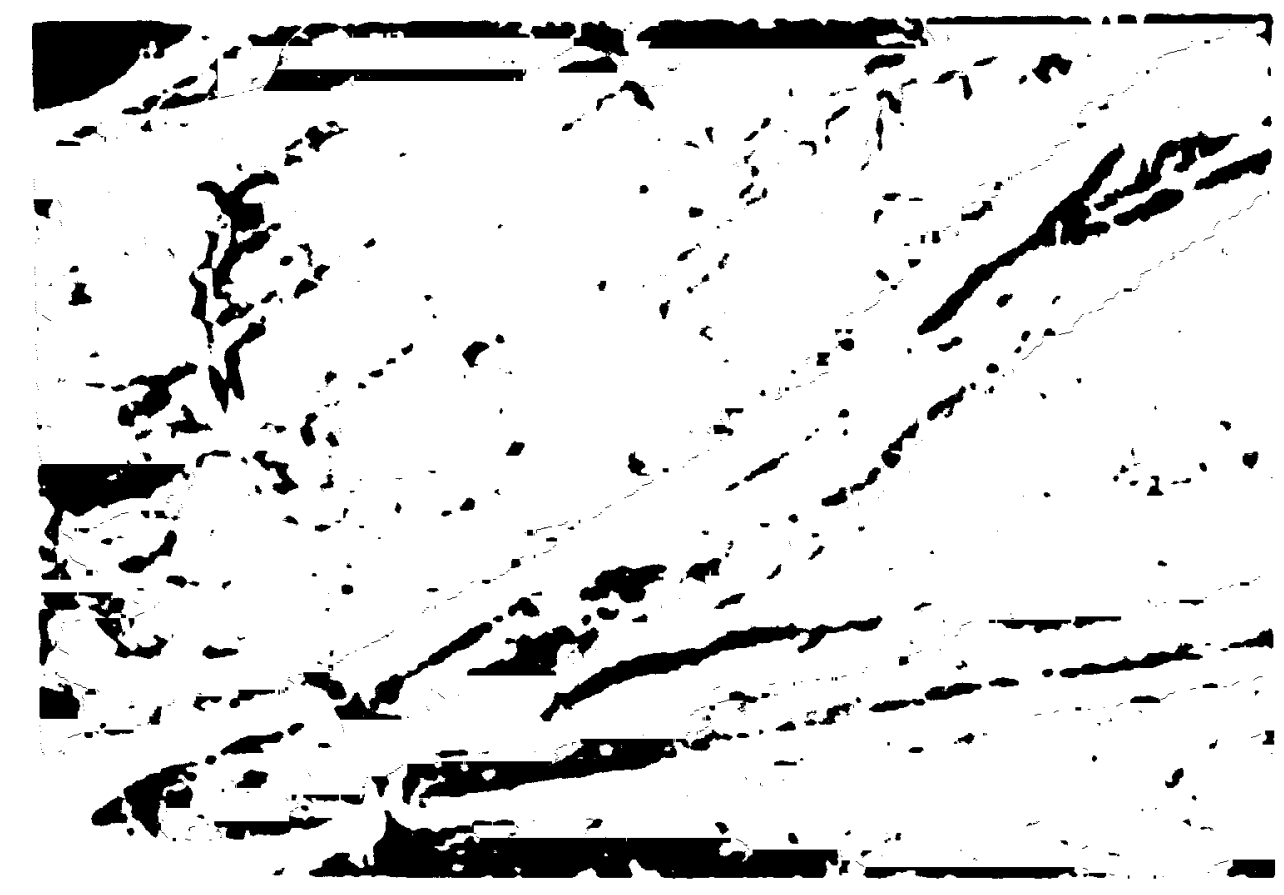

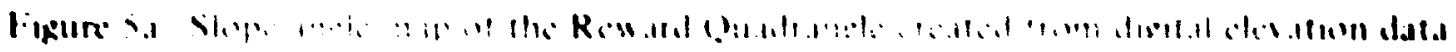

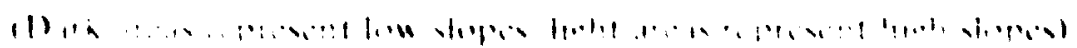

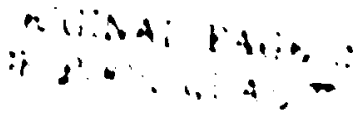




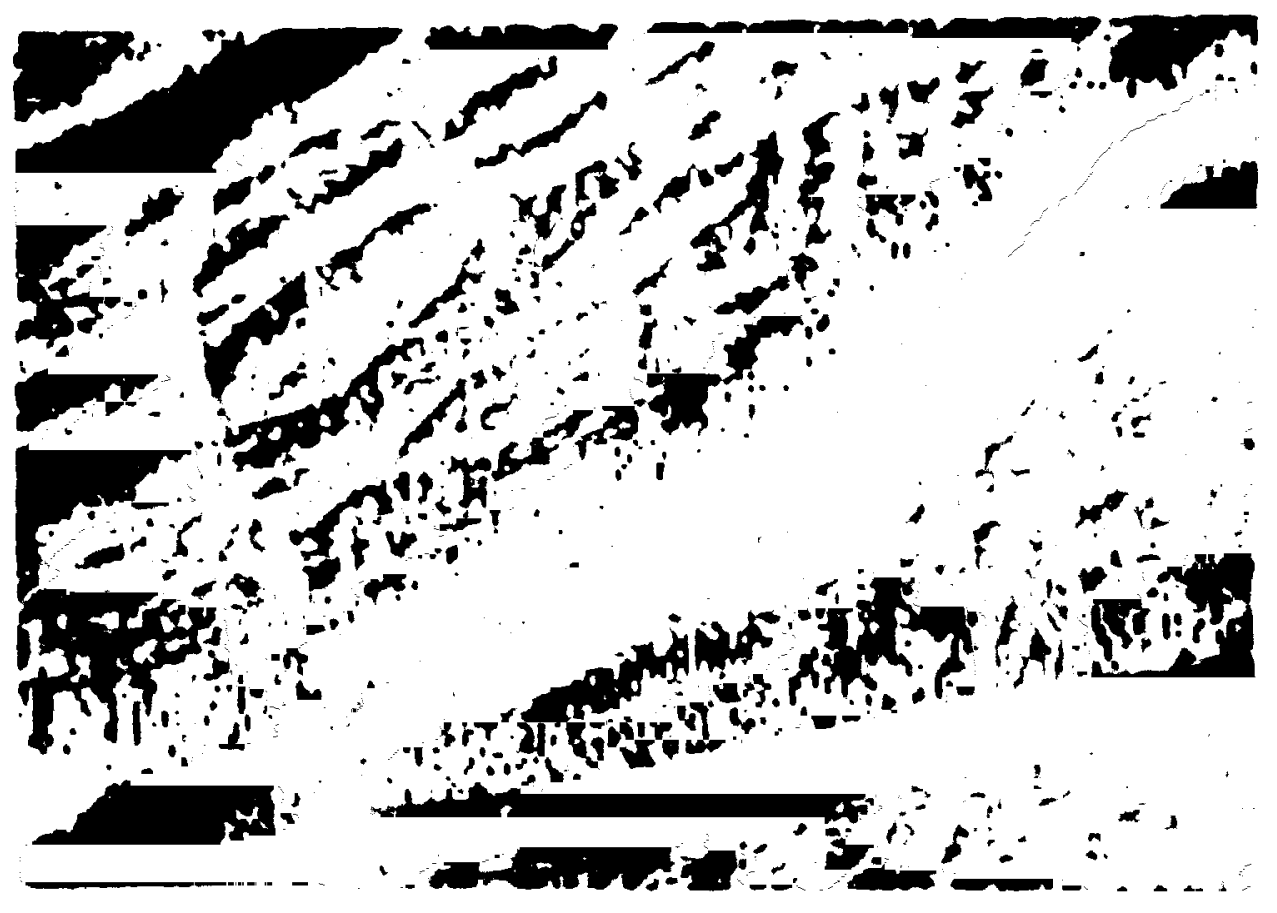

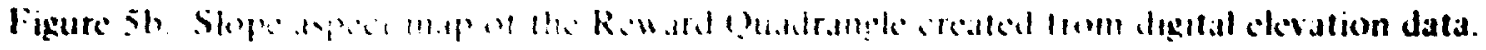

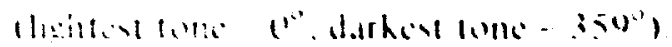

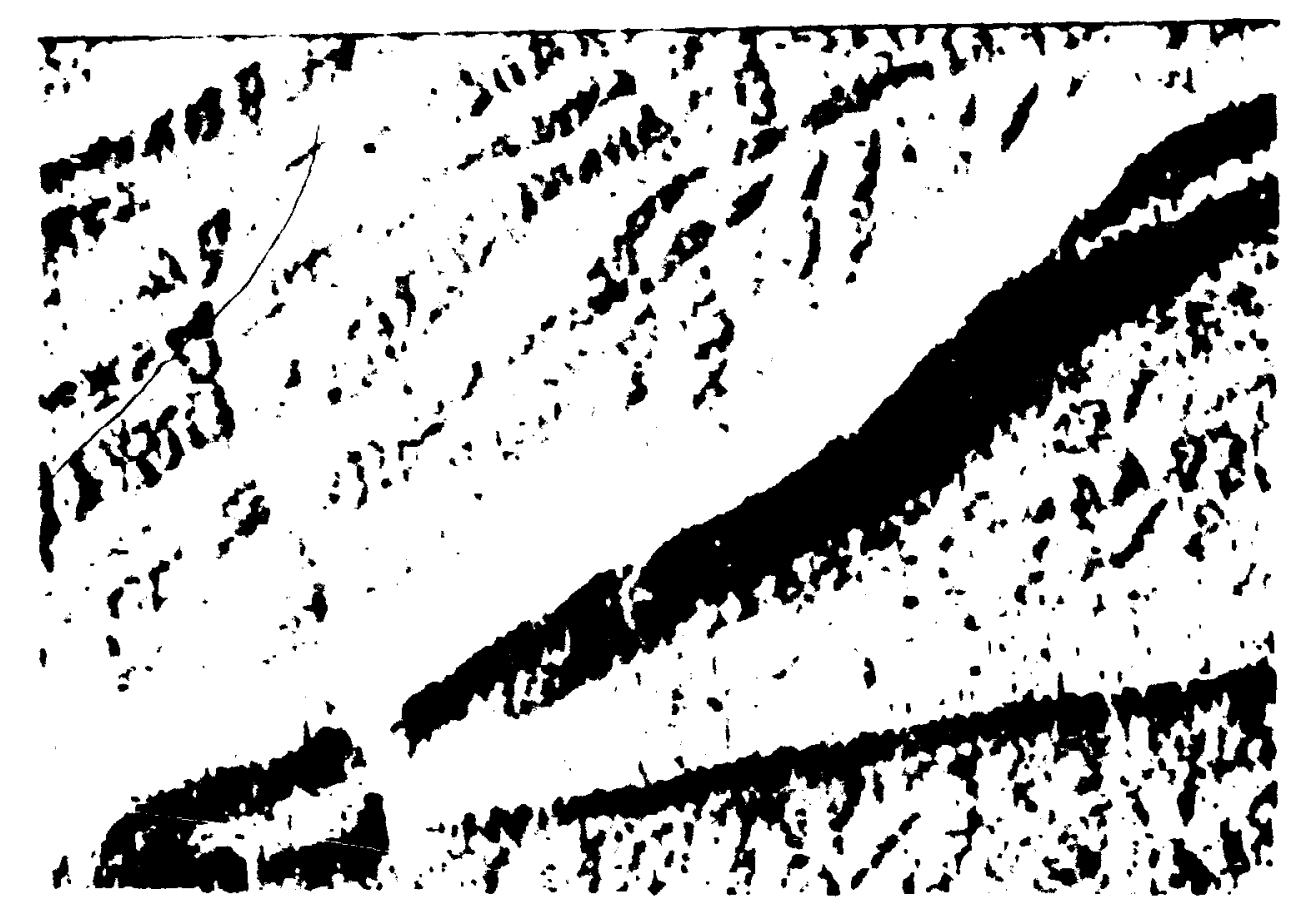

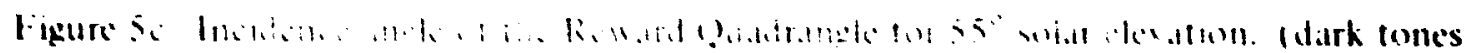

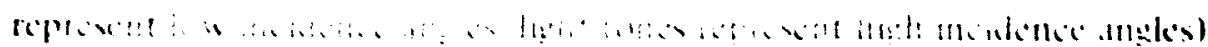




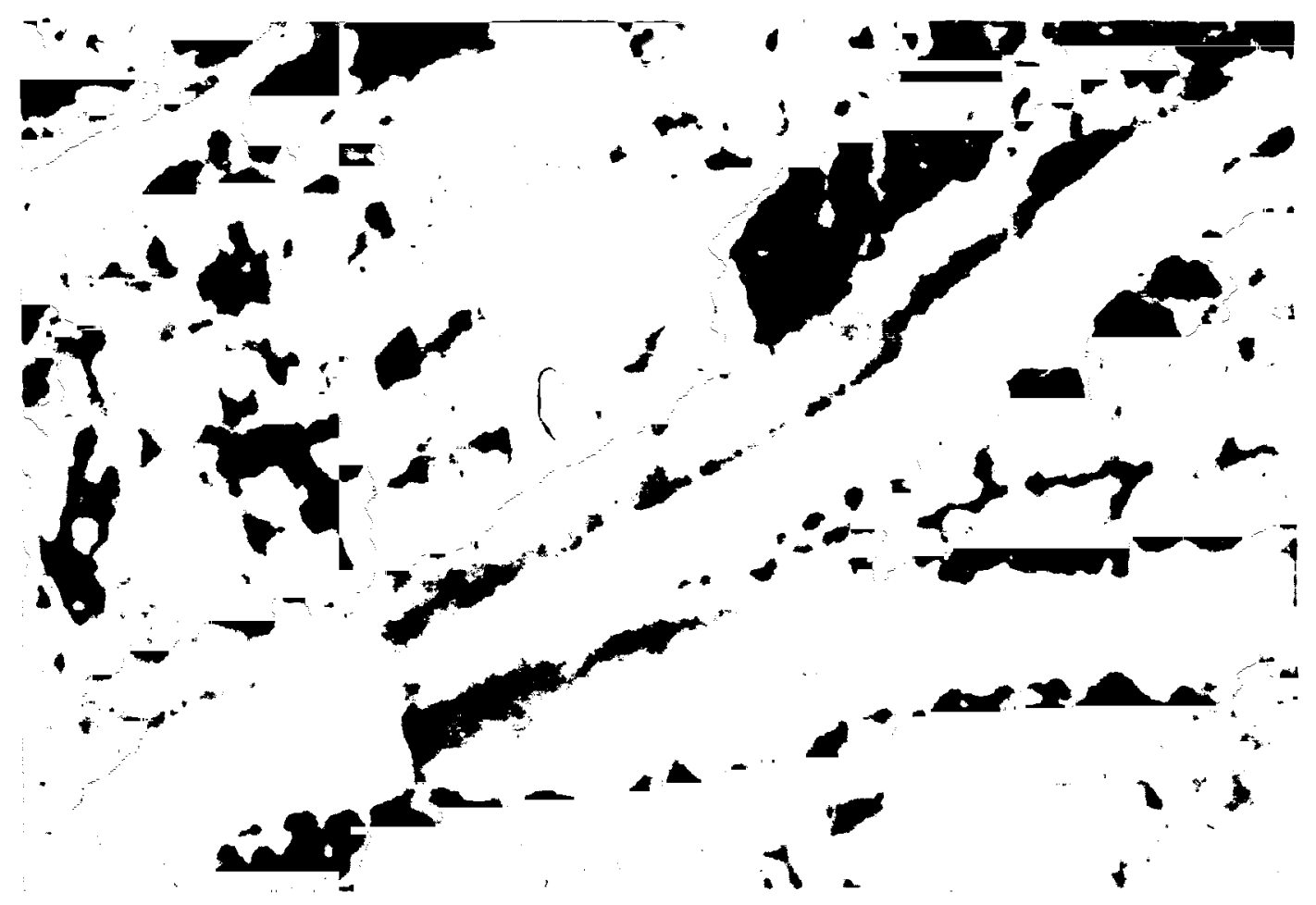

1 grure 6. Lamdsat MSS ${ }^{\rightarrow}$ of the Rew ard Quadrangle.
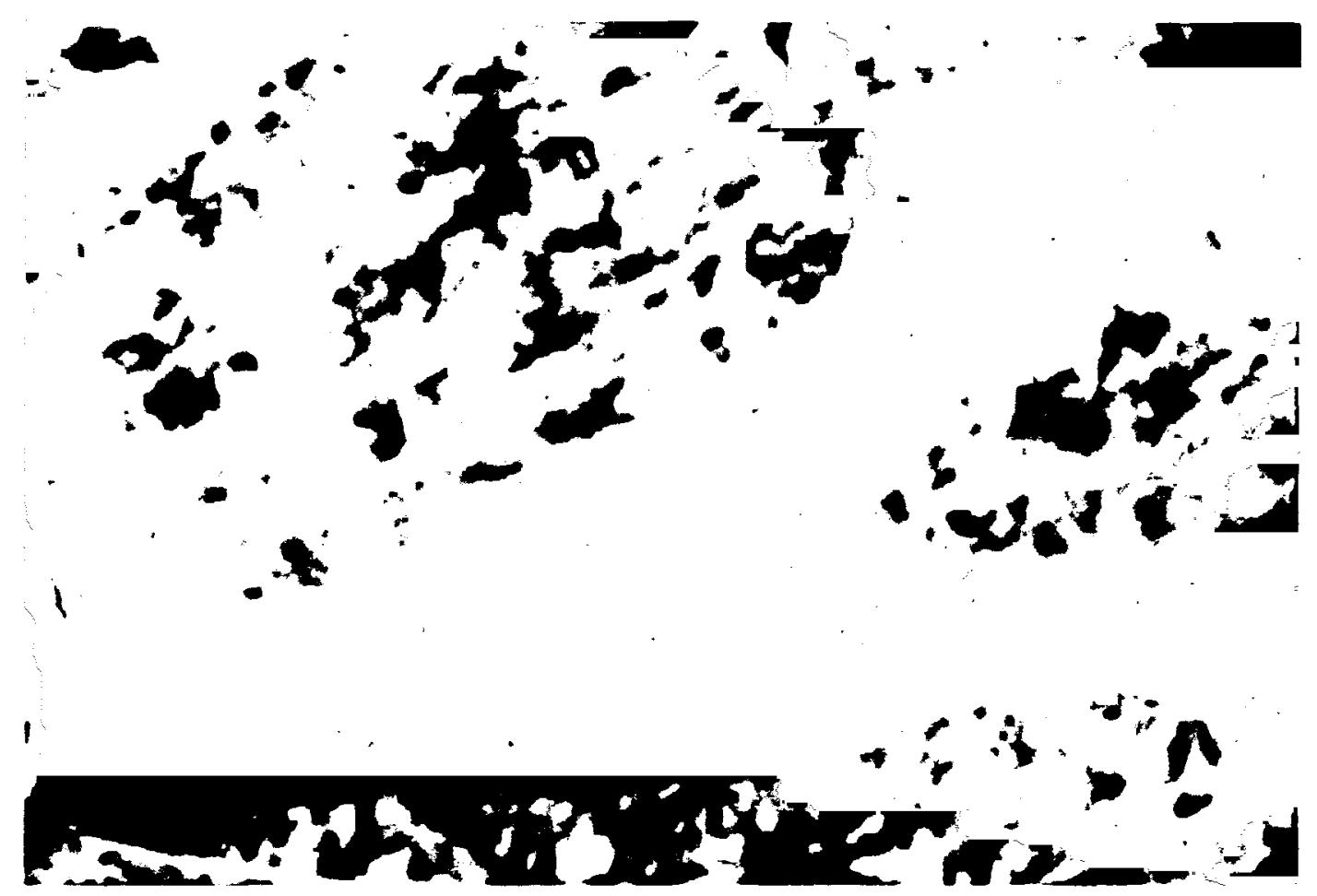

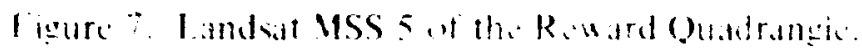

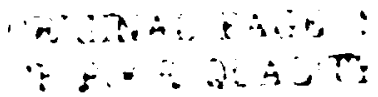




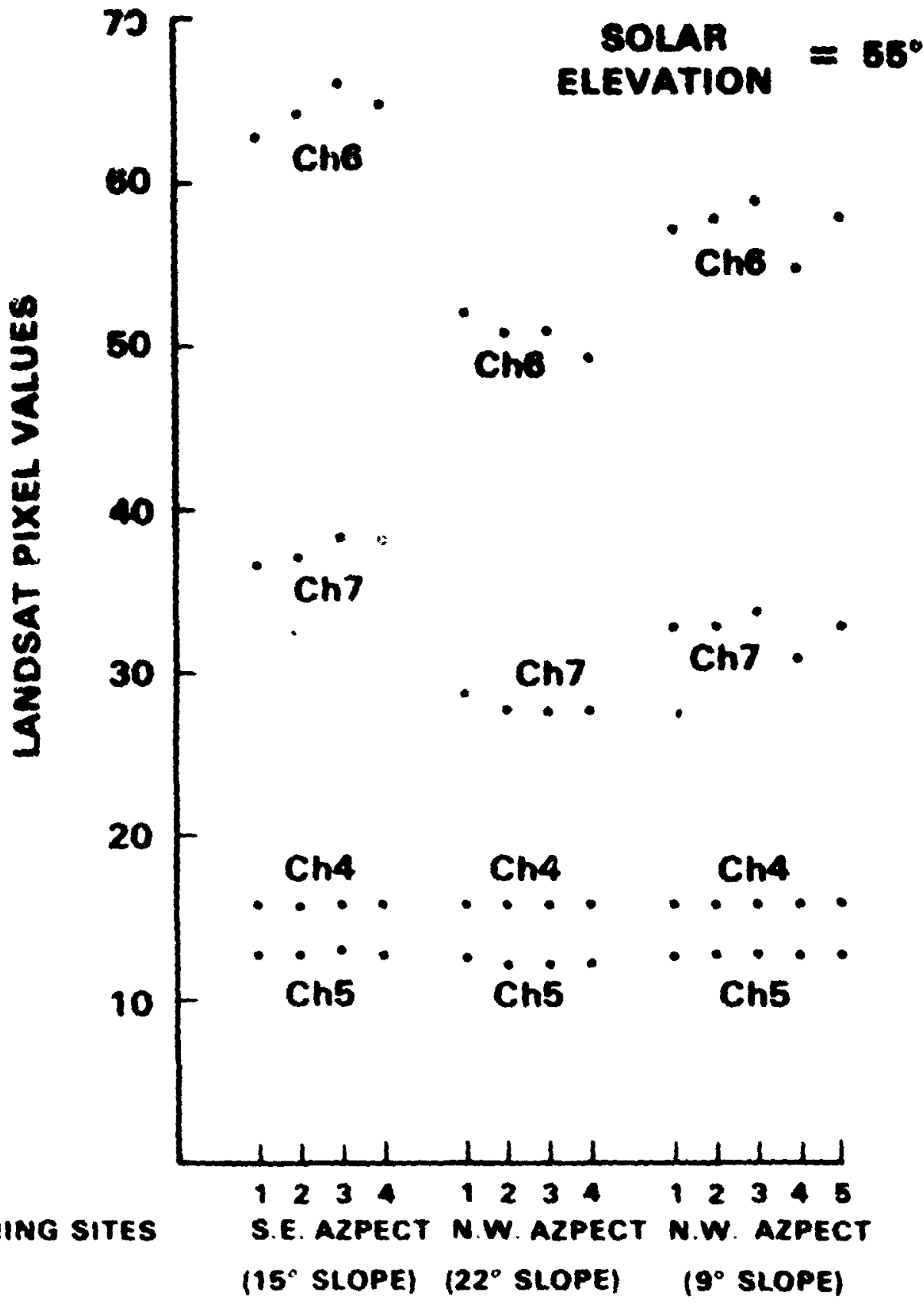

Figure 8. Plot showing the distritution of moan Landsat pixel values associated with the tratning sites from different slopes and aspects. 

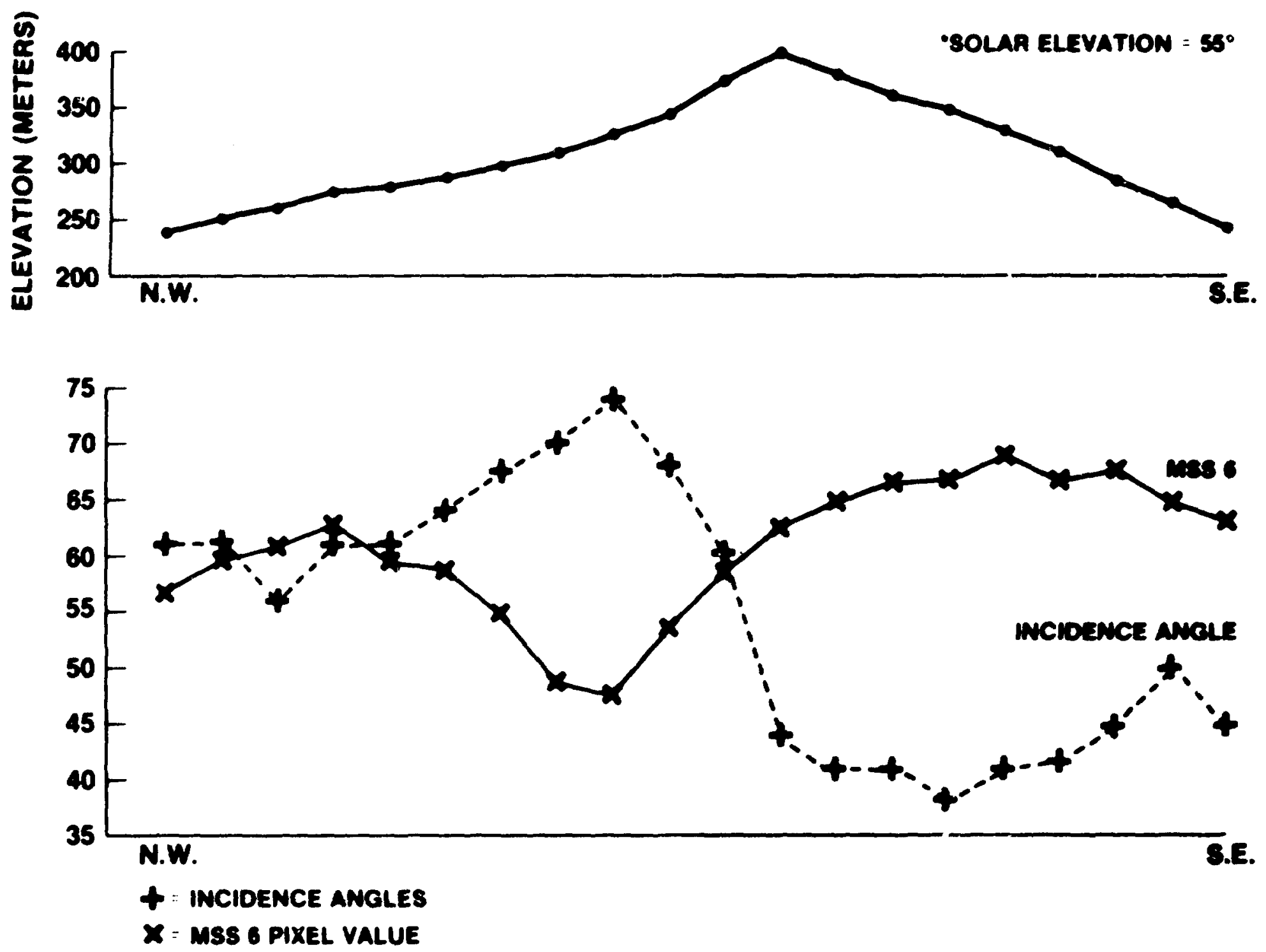

Figure 9. Hevation, incidence angles. and Landsat multispect tal saanner to response for a xample transect across Buffato Mountain. 


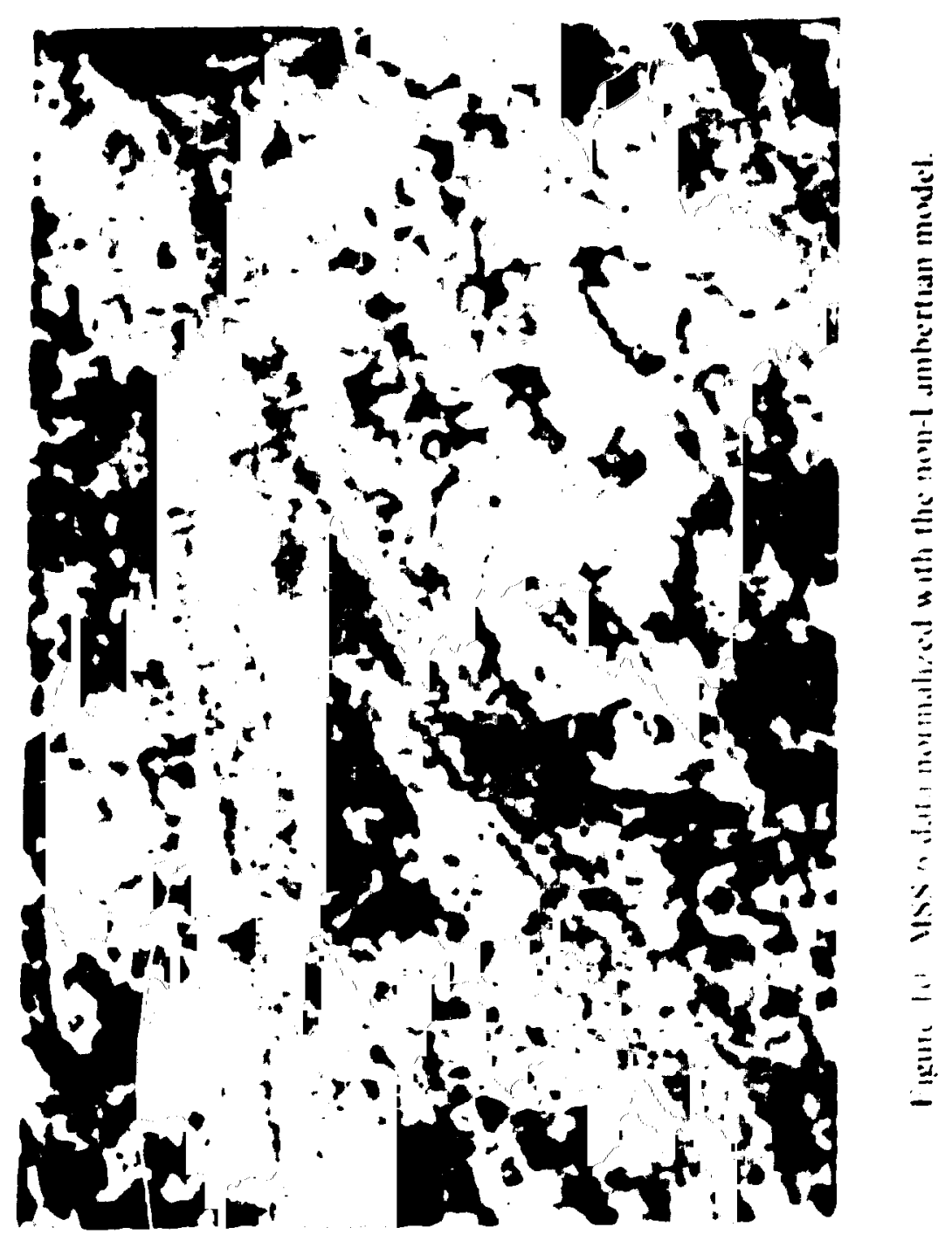



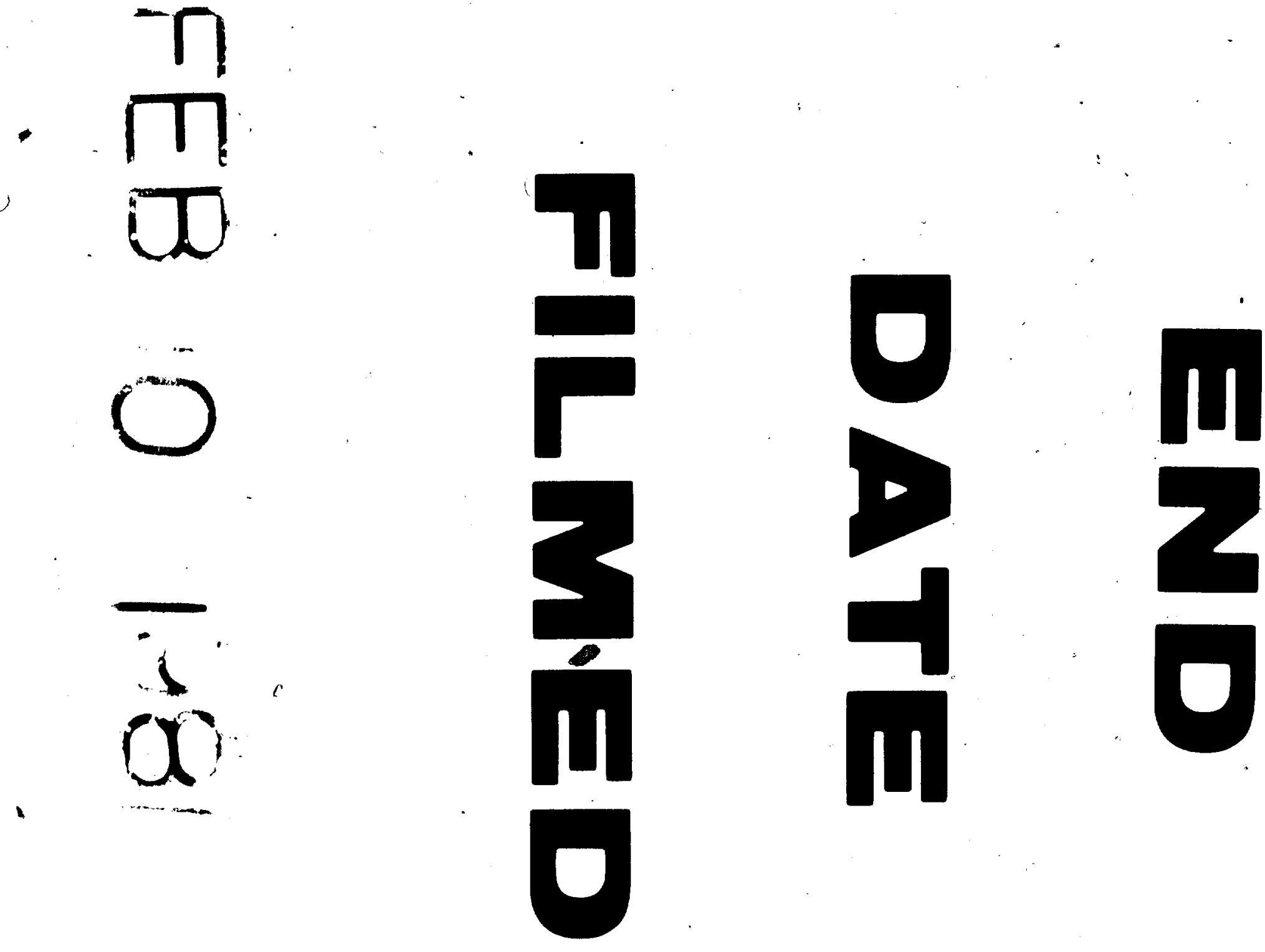